\title{
Tbr2 Expression in Cajal-Retzius Cells and Intermediate Neuronal Progenitors Is Required for Morphogenesis of the Dentate Gyrus
}

\author{
Rebecca D. Hodge, ${ }^{1,2}$ Alfredo J. Garcia III, ${ }^{2}$ Gina E. Elsen, ${ }^{2}$ Branden R. Nelson, ${ }^{1,2}$ Kristin E. Mussar, ${ }^{2}$ Steven L. Reiner, ${ }^{3}$ \\ Jan-Marino Ramirez, ${ }^{1,2}$ and Robert F. Hevner ${ }^{1,2}$ \\ ${ }^{1}$ Department of Neurological Surgery, University of Washington, Seattle, Washington 98101, ${ }^{2}$ Center for Integrative Brain Research, Seattle Children's \\ Research Institute, Seattle, Washington 98101, and ${ }^{3}$ Departments of Microbiology, Immunology, and Pediatrics, College of Physicians and Surgeons, \\ Columbia University, New York, New York 10032
}

The dentate gyrus (DG) is a unique cortical region whose protracted development spans the embryonic and early postnatal periods. DG development involves large-scale reorganization of progenitor cell populations, ultimately leading to the establishment of the subgranular zone neurogenic niche. In the developing DG, the T-box transcription factor Tbr2 is expressed in both Cajal-Retzius cells derived from the cortical hem that guide migration of progenitors and neurons to the DG, and intermediate neuronal progenitors born in the dentate neuroepithelium that give rise to granule neurons. Here we show that in mice $T b r 2$ is required for proper migration of Cajal-Retzius cells to the DG; and, in the absence of Tbr2, formation of the hippocampal fissure is abnormal, leading to aberrant development of the transhilar radial glial scaffold and impaired migration of progenitors and neuroblasts to the developing DG. Furthermore, loss of Tbr2 results in decreased expression of $\mathrm{Cxcr} 4$ in migrating cells, leading to a premature burst of granule neurogenesis during early embryonic development accompanied by increased cell death in mutant animals. Formation of the transient subpial neurogenic zone was abnormal in Tbr2 conditional knock-outs, and the stem cell population in the DG was depleted before proper establishment of the subgranular zone. These studies indicate that $T b r 2$ is explicitly required for morphogenesis of the DG and participates in multiple aspects of the intricate developmental process of this structure.

\section{Introduction}

The dentate gyrus (DG) has a prolonged developmental period that spans embryonic and early postnatal stages and involves large-scale reorganization of progenitor cells (Pleasure et al., 2000; Li and Pleasure, 2005; Li et al., 2009). DG development commences as neural stem cells (NSCs) located in the dentate neuroepithelium (DNe) begin to proliferate (see Fig. 1A). NSCs exit the $\mathrm{DNe}$ and migrate along the dentate migratory stream (DMS) to form the transient subpial neurogenic zone (SPZ), which organizes around the pole of the developing DG and begins to generate neurons that seed the suprapyramidal blade of

\footnotetext{
Received Aug. 31, 2012; revised Jan. 8, 2013; accepted Jan. 14, 2013

Author contributions: R.D.H., A.J.G., B.R.N., J.-M.R., and R.F.H. designed research; R.D.H., A.J.G., G.E.E., and K.E.M. performed research; S.L.R. contributed unpublished reagents/analytic tools; R.D.H. and R.F.H. analyzed data; R.D.H., A.J.G., and R.F.H. wrote the paper.

This work was supported by NIMH Grants 3R01-MH080766 and R01-MH058869 to R.F.H., R.D.H. received fellowships from the Heart \& Stroke Foundation of Canada and the American Heart Association (Grant 10P0ST2610067). We thank Roderick Yang for technical assistance; S.J. Pleasure (University of California, San Francisco) who provided the Prox 1 antibody as well as $\mathrm{C} x \mathrm{Cr} 4$ and $\mathrm{Cx} / 12$ plasmids; E. Grove (University of Chicago) who provided plasmids for Wnt3a and Wnt5a; G. Enikolopov (Cold Spring Harbor Laboratories) who provided Nestin-GFP mice; and R. Kageyama (Kyoto University) who provide Nestin-CreER ${ }^{\mathrm{T} 2}$ mice.

The authors declare no competing financial interests.

Correspondence should be addressed to either Dr. Rebecca D. Hodge or Dr. Robert F. Hevner, Seattle Children's Research Institute, Center for Integrative Brain Research, MS C9S-10, 1900 9th Avenue, Seattle, WA 98101, E-mail: rdhodge@uw.edu or rhevner@uw.edu.

DOI:10.1523/JNEUROSCI.4185-12.2013

Copyright $\odot 2013$ the authors $\quad 0270-6474 / 13 / 334165-16 \$ 15.00 / 0$
}

the granule cell layer (GCL) ( $\mathrm{Li}$ and Pleasure, 2005; Li et al., 2009). Ultimately, NSCs undergo a second reorganization to establish the subgranular zone (SGZ), the neurogenic niche maintained throughout adulthood (see Fig. 1). During postnatal development, NSCs in the SGZ and DMS continue to generate granule neurons that expand both the suprapyramidal and infrapyramidal blades, giving the DG its characteristic arrowhead shape.

Relatively little is known about factors controlling transit of NSCs and neurons to the developing DG. However, CajalRetzius cells, which express Reelin, appear to have a special role in orchestrating DG morphogenesis (Forster et al., 2002; Frotscher et al., 2003; Sibbe et al., 2009). Specifically, Reelin is necessary for proper formation of the transhilar radial glial scaffold that guides migration of cells to the developing DG (Forster et al., 2002; Frotscher et al., 2003). Additionally, Reelin has been implicated in controlling exit of progenitor cells from the SPZ (Li et al., 2009), suggesting that it is a critical regulator of multiple aspects of DG development.

$T b r 2$, a T-box transcription factor (TF), regulates glutamatergic fate specification in a variety of brain regions, including the DG (Hevner et al., 2006; Hodge et al., 2012). Previous work from our laboratory showed that Tbr2 is specifically expressed in DG intermediate neuronal progenitors (INPs) and established this $\mathrm{TF}$ as a critical regulator of neurogenesis in the developing and adult DG (Hodge et al., 2008; Hodge et al., 2012). Here we show 
that Tbr2 has additional, novel functions during DG morphogenesis, distinct from its role in regulating neurogenesis. Specifically, we show that Tbr2 is expressed in Cajal-Retzius cells derived from the cortical hem and that ablation of Tbr2 in these cells results in ectopic accumulation of Cajal-Retzius cells during their migration to the developing DG. Concurrently, invagination of the pial surface to form the hippocampal fissure (HF) is delayed, and development of the transhilar radial glial scaffold is aberrant. Moreover, we show that Tbr2 ablation results in decreased CXcr4 expression, suggesting that chemokine signaling is also impaired in the absence of Tbr2. Downstream consequences of these defects include accumulation of NSCs in the SPZ in conditional Tbr2 knock-out mice (Nestin-Cre; Tbr ${ }^{\text {flox/flox }}$ ). Subsequently, NSCs fail to localize to the SGZ, leading to a near-complete absence of the adult neurogenic niche. Together, these results suggest that Tbr2 expression is critical for the execution of a series of events that cumulatively orchestrate the complex developmental plan of the DG.

\section{Materials and Methods}

Animals. Tbr $2^{\text {flox }}$, Nestin-Cre, Nestin-CreER ${ }^{\mathrm{T} 2}$, and Nestin-GFP mice have been previously described (Tronche et al., 1999; Mignone et al., 2004; Imayoshi et al., 2006; Intlekofer et al., 2008). Animals were maintained on a C57Bl/6 background in the vivarium at Seattle Children's Research Institute. Institutional Animal Care and Use Committees at Seattle Children's Research Institute and the University of Washington approved animal procedures. For experiments using Nestin-Cre, control animals were either Nestin-Cre; $T b r 2^{\text {flox/+ }}$ or Tbr $2^{\text {llox/+ }}$. No differences between these genotypes were observed with respect to brain weight, morphology of the DG, and cell numbers; accordingly, these mice were grouped together as controls (Hodge et al., 2012). Experimental animals were Nestin-Cre;Tbr2 $2^{\text {flox/flox }}$. For experiments using the tamoxifeninducible Nestin-CreER ${ }^{\mathrm{T} 2}$, control animals were Nestin-CreER ${ }^{\mathrm{T} 2}$; $\mathrm{Tbr} 2^{\text {flox/+ }}$ and experimental animals were Nestin-CreER ${ }^{\mathrm{T} 2} ; \mathrm{Tbr} 2^{\text {flox/flox }}$. To generate embryonic mice, timed matings were used with the day of the vaginal plug considered embryonic day (E) 0.5. Embryos were harvested as described previously (Englund et al., 2005). To collect tissues at postnatal time points, animals were deeply anesthetized with Avertin (Sigma) and transcardially perfused with $4 \%$ PFA as described previously (Hodge et al., 2012). For BrdU pulse-chase experiments, pregnant females were injected with $\mathrm{BrdU}(50 \mathrm{mg} / \mathrm{kg}$ ) on E15.5, and embryos were collected on E17.5.

Tamoxifen treatment. Tamoxifen (Sigma) was dissolved in corn oil (Fisher Scientific) at a concentration of $25 \mathrm{mg} / \mathrm{ml}$. Pregnant females were injected with tamoxifen (i.p.) on E13.5 and E14.5 at a dosage of 180 $\mathrm{mg} / \mathrm{kg}$ body weight. Embryos were subsequently collected on E19.5.

Tissue preparation, immunohistochemistry, and in situ hybridization. Brains of embryonic animals were removed from the skull and placed in $4 \%$ PFA for $2-4 \mathrm{~h}$, transferred to $30 \%$ sucrose, and stored at $4^{\circ} \mathrm{C}$ until they were embedded in OCT (TissueTek). Brains were sectioned at 15-20 $\mu \mathrm{m}$ on a cryostat, mounted on Superfrost Plus glass slides (Fisher Scientific), and stored at $-80^{\circ} \mathrm{C}$. Postnatal brains were fixed for $2-4 \mathrm{~h}$ after perfusion with $4 \%$ PFA and were sectioned either at $20 \mu \mathrm{m}$ on a cryostat as above or at $40 \mu \mathrm{m}$ free floating. Floating sections were transferred to cryoprotectant solution, as described previously (Hodge et al., 2008), and stored at $-20^{\circ} \mathrm{C}$. Primary antibodies used in the present study were chicken anti-GFP (Abcam; 1:500), rabbit anti-Tbr2 (laboratory of R.F.H.; 1:1000), rat anti-Tbr2 (EB Bioscience; 1:250), mouse anti-PCNA (Millipore; 1:1000), rabbit anti-p73 (Santa Cruz Biotechnology; 1:75), rabbit anti-Prox1 (S. Pleasure; 1:500), goat anti-NeuroD1 (Santa Cruz Biotechnology; 1:400), mouse anti-calretinin (Millipore; 1:1000), goat anti-Sox2 (Santa Cruz Biotechnology; 1:400), rabbit anti-Blbp (Abcam; 1:1000), rat anti-Ctip2 (Abcam; 1:500), mouse anti-Reelin (Calbiochem; 1:1000), rabbit anti-Gfap (Dako; 1:1000), and rabbit anti-activated caspase-3 (AC3, Cell Signaling Technologies; 1:500). Sections were processed for the detection of antigens of interest using AlexaFluorconjugated fluorescent secondary antibodies (Invitrogen) as previously described (Hodge et al., 2008). Nissl stains were performed as described previously (Hodge et al., 2005). In situ hybridization was performed on slide-mounted tissues exactly as previously described (Bedogni et al., 2010). Plasmids to make in situ probes for Cxcl12 and Cxcr4 were obtained from S. Pleasure (University of California, San Francisco), and $W n t 3 a$ and Wnt5a were from E. Grove (University of Chicago).

Cell counting and surface area measurements. Cell densities (Reelin ${ }^{+}$, Prox $1^{+}, \mathrm{AC}^{+}$cells) were assessed by conducting cell counts on every 10th $20 \mu \mathrm{m}$ section through the rostrocaudal extent of the DG $(N=3$ animals per group). Images were obtained using a Zeiss LSM 710 confocal microscope equipped with a $40 \times, 1.3 \mathrm{NA}$ oil objective. Cells intersecting the top plane of focus were excluded from counts, and total cell numbers were divided by the total counting area to give the number of cells per millimeter squared. To determine the proportion of Sox $2^{+}$cells coexpressing Prox 1 , total numbers of Sox $2^{+}$, Sox $2^{+} / \operatorname{Prox} 1^{+}$, and Prox $1^{+}$cells were counted on 3 nonconsecutive sections through the $\mathrm{DG}$, and the total number of Sox $2^{+} / \operatorname{Prox} 1^{+}$cells was divided by the total number of Sox ${ }^{+}$cells. For BrdU pulse-chase experiments, total numbers of $\mathrm{BrdU}^{+}$and $\mathrm{BrdU}^{+} / \operatorname{Prox} 1^{+}$cells were counted on 3 nonconsecutive sections per animal, and the proportion of $\mathrm{BrdU}^{+} / \operatorname{Prox} 1^{+}$cells was determined by dividing by the total number of $\mathrm{BrdU}^{+}$cells. The surface area of the HF was measured as previously described (Hodge et al., 2005).

Electrophysiology. Whole-cell patch-clamp recordings were made from within the GCL of the DG in hippocampal brain slices $(400-550 \mu \mathrm{m}$ thick; P15-P30). All recordings were conducted in current-clamp configuration (sampled at $20 \mathrm{kHz}$ ) using a multiclamp amplifier and Clampex 10.0 software (Molecular Devices). Borosilicate glass recording electrodes (4-8 M $\Omega$ ) were prepared using a P-97 Flaming/Brown micropipette puller (Sutter Instrument) and filled with intracellular patch electrode solution containing (in $\mathrm{mm}$ ) the following: $140 \mathrm{~K}$-gluconic acid, $1 \mathrm{CaCl}_{2}, 10$ EGTA, $2 \mathrm{MgCl}_{2}, 4 \mathrm{Na}_{2} \mathrm{ATP}, 10$ HEPES (pH 7.2). Upon establishing a stable intracellular recording, a current injection step protocol ( -120 to $20 \mathrm{pA}$ with a $20 \mathrm{pA}$ step) was performed. Measurements were made in triplicate. The mean value of the triplicate measurements was considered as the response of a given neuron during the aforementioned conditions. The calculated junction potential of $12 \mathrm{mV}$ was subtracted post hoc from membrane potential $\left(\mathrm{V}_{\mathrm{m}}\right)$. Input resistance $\left(\mathrm{R}_{\mathrm{n}}\right)$ of each neuron was calculated using the changes in $V_{m}$ that resulted from the hyperpolarizing current injections. The number of action potentials generated by injecting $20 \mathrm{pA}$ was also determined.

Statistical analyses. Statistical analyses were conducted using either ANOVA with Bonferroni post hoc analysis or a two-sample $t$ test where appropriate and as indicated using SPSS statistical software (IBM). Differences were considered statistically significant at $p<0.05$.

\section{Results}

\section{Early development of the cortical hem and DNe is normal in} the absence of $T b r 2$

Previous work from our laboratory showed that Tbr2 protein is expressed throughout DG development (Hodge et al., 2012); however, the function of Tbr2 during initial development of the DNe was unclear from these studies. We first examined Tbr2 protein expression on E12.5 and found that Tbr2 was expressed in the cortical hem adjacent to the DNe and in the DNe itself in control animals (Fig. 1G,G1). However, in Nestin-Cre; $\mathrm{Tbr}{ }^{\text {flox/flox }}$ mice, Tbr2 was effectively ablated from the cortical hem and DNe by E12.5 (Fig. $1 \mathrm{H}, \mathrm{H1}$ ). To determine whether ablation of Tbr2 affected development of the cortical hem, we examined several signaling molecules specifically expressed in this region (Fig. $1 A, I, L)$. We found that the cortical hem specific genes Wnt $3 a$ and Wnt5a (Grove et al., 1998; Shimogori et al., 2004) were expressed at levels approximately equivalent to controls in Nestin-Cre; Tbr $2^{\text {flox/flox }}$ mice at E12.5 despite ablation of Tbr2 in the cortical hem (Fig. 1I-L). As well, early formation of the DNe appeared largely normal (Fig. 1M-N1) despite the ab- 

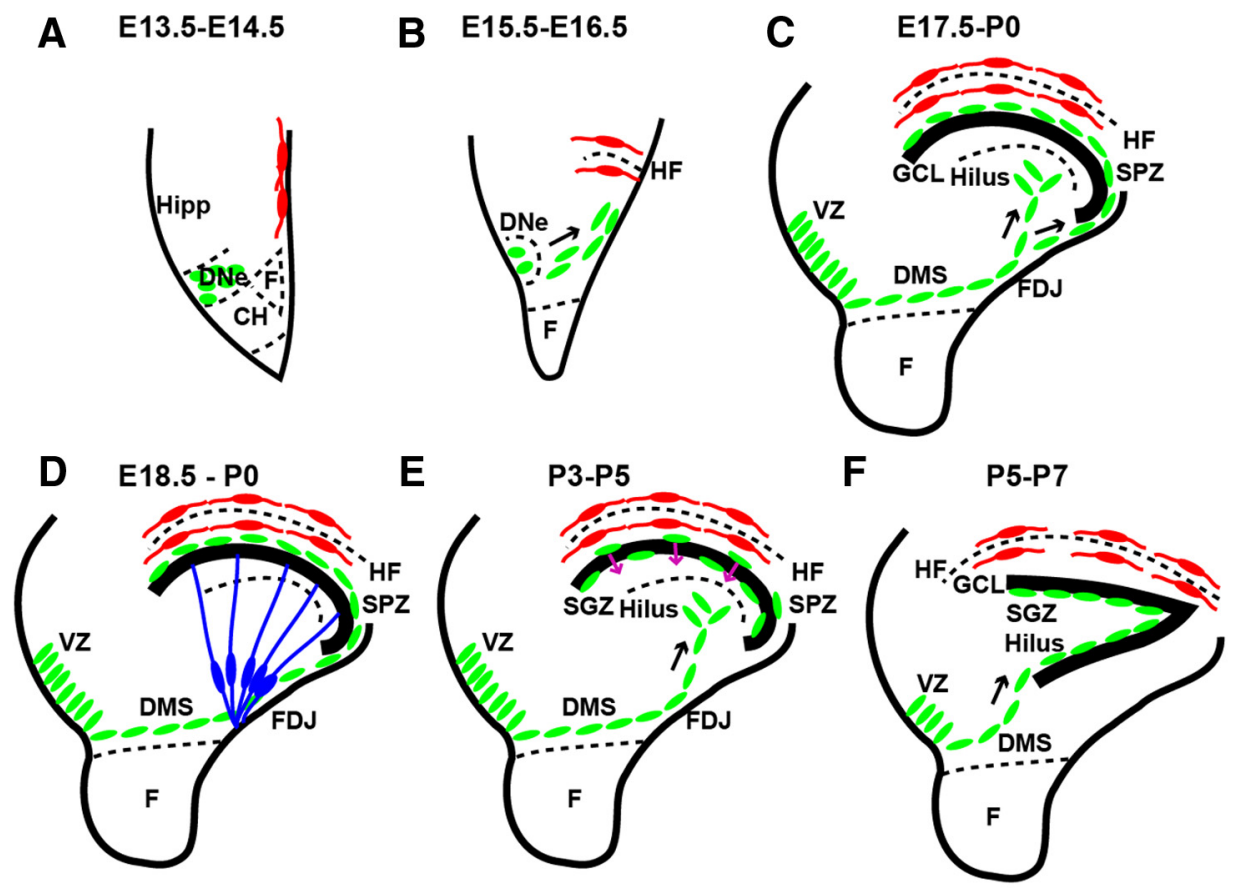

- Progenitor cells (NSCs and INPs)

Cajal-Retzius cells

Radial glia cells of the transhilar glial scaffold
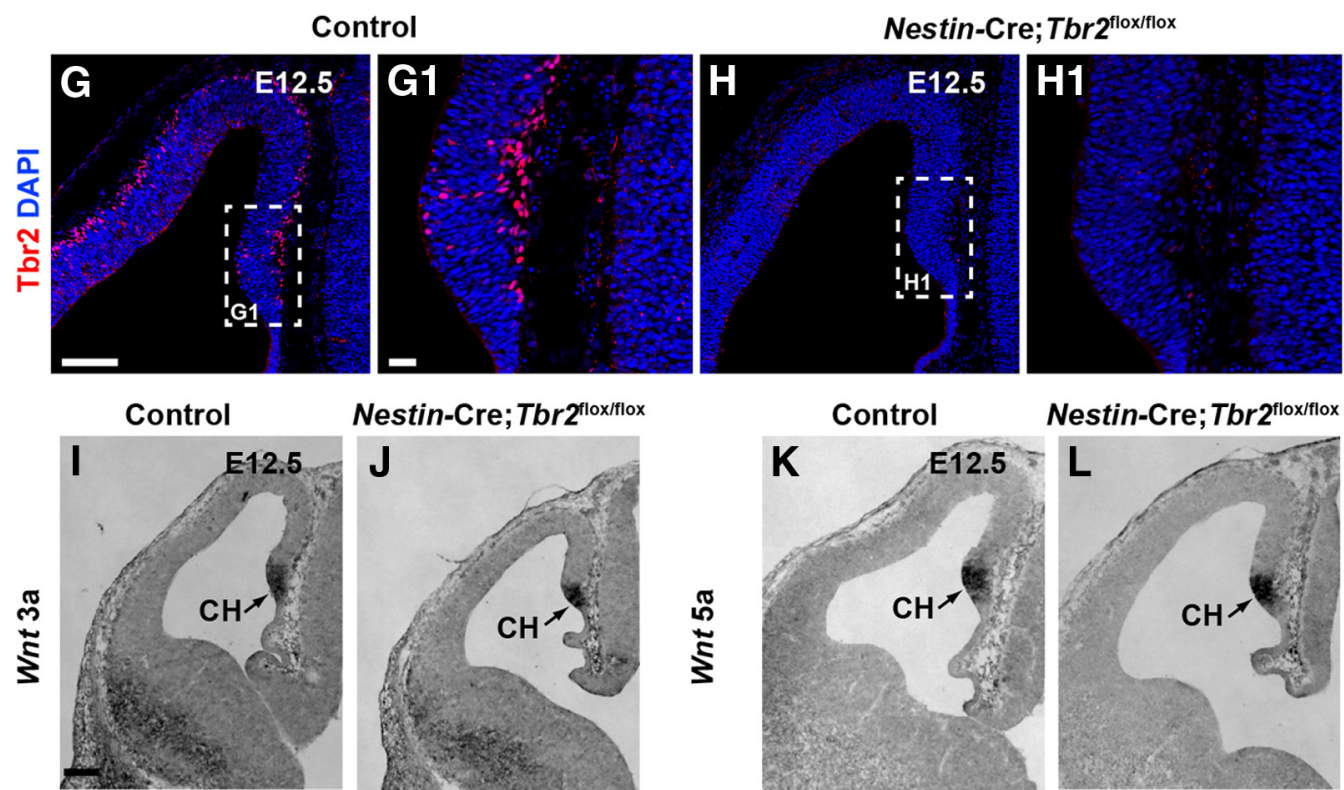

Nestin-Cre; Tbr2 $2^{\text {flox/flox }}$

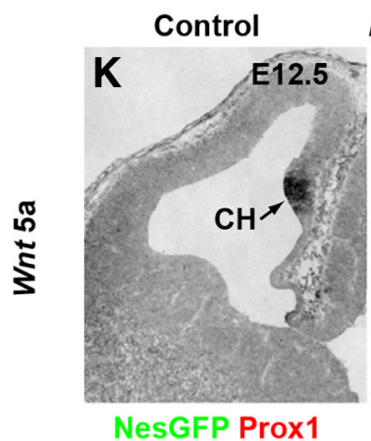

Nestin-Cre;Tbr2 flox/flox
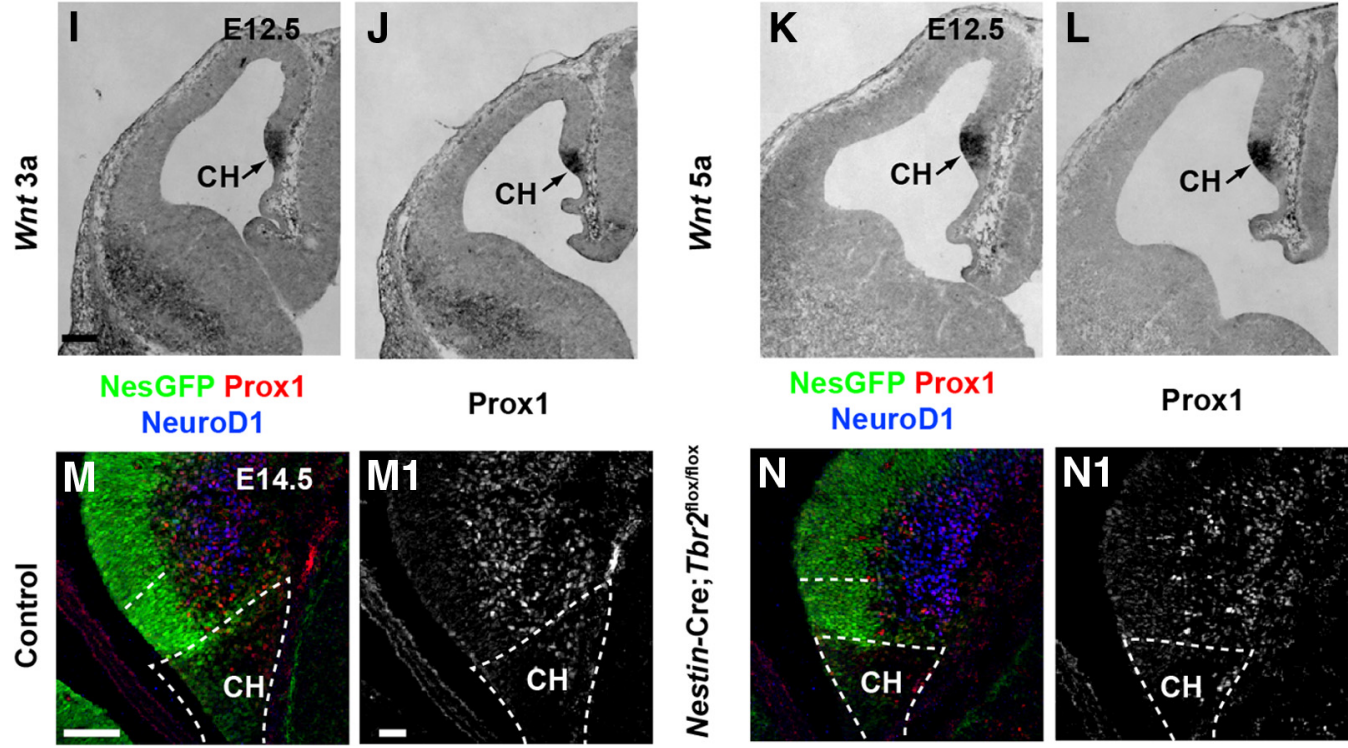

Figure 1. Early development of the DG is essentially normal in Nestin-Cre;Tbr $2^{\text {flox/flox }}$ mice. $A-F$, Schematic diagram illustrating the steps in DG development. Green represents progenitor cells (NSCs and INPs); red, Cajal-Retzius cells; blue, transhilar radial glial scaffold. $A, B$, Progenitor cells initially located in the DNe migrate to the primordial DG concurrent with invagination of the pial surface and migration of Cajal-Retzius cells to the HF between E13.5 and E16.5. C, Continued migration of progenitors through the DMS contributes to formation of the SPZ during later stages of development (E17.5-P0). D, The transhilar radial scaffold forms at approximately the same time as radial glia become localized to the FDJ. (Figure legend continues.) 
sence of Tbr2 in mutant mice. In Nestin-Cre;Tbr $2^{\text {flox/flox }}$ mice, approximately equal numbers of Nestin-GFP ${ }^{+}$NSCs were present in the $\mathrm{DNe}$ (Fig. $1 M, N)$. However, we noted that there was an apparent slight reduction in NeuroD $1^{+}$and Prox $1^{+}$cells in the developing DG in Nestin-Cre; Tbr $2^{\text {flox/flox }}$ animals compared with control mice at E14.5 (Fig. 1M-N1), consistent with the role of Tbr2 in DG neurogenesis (Hodge et al., 2012).

\section{Aberrant development of the $\mathrm{HF}$ and ectopic accumulation of Reelin ${ }^{+}$cells in Nestin-Cre;Tbr $2^{\text {flox/flox }}$ mice}

To assess the effect of Tbr 2 conditional deletion on DG morphogenesis, we examined the formation of two morphogenic landmarks: the HF and the transhilar radial glial scaffold (Frotscher et al., 2003; Li et al., 2009; Sibbe et al., 2009). Because Reelin ${ }^{+}$ Cajal-Retzius cells were previously implicated in orchestrating DG morphogenesis (Forster et al., 2002; Frotscher et al., 2003; Sibbe et al., 2009), we began our analysis with this cell population. As mentioned previously, we observed clear expression of Tbr2 protein in the cortical hem (Figs. 1G,G1 and Fig. 2A-A3). Consistent with previous reports (Englund et al., 2005; Gu et al., 2011), we confirmed that Tbr2 protein was expressed in CajalRetzius cells in the cortical hem by examining coexpression of Tbr2 and the Cajal-Retzius cell markers p73 and Reelin. At E14.5, the majority of Tbr $2^{+}$cells in the cortical hem coexpressed p73 (Fig. 2A-A3), and extensive coexpression of Tbr2 and Reelin was also observed at this age, suggesting that most cortical hemderived Cajal-Retzius cells express Tbr2 during their generation (Fig. 2C,C1). These findings suggest that Tbr2 may have unique functions within Cajal-Retzius cells distinct from its role in INPs (Fig. 2A,A3).

To examine the functions of Tbr2 in Cajal-Retzius cells, levels of Reelin expression were assessed in the cortical hem of E14.5 control and Nestin-Cre;Tbr $2^{\text {flox/flox }}$ mice. We found that Reelin was expressed at approximately equal levels on a per cell basis in the cortical hem of Nestin-Cre;Tbr $2^{\text {flox/flox }}$ mice and control embryos, suggesting that Tbr2 is not required for Reelin expression in Cajal-Retzius cells (Fig. 2C,C1,D,D1). However, in NestinCre; Tbr $2^{\text {flox/flox }}$ mice, Tbr2 protein was absent from CajalRetzius cells in the cortical hem (Fig. $2 B-B 3, D, D 1$ ) at E14.5, confirming ablation of Tbr2 in these cells in mutants. Despite this lack of Tbr 2 expression in Cajal-Retzius cells, the density of $\mathrm{p} 73^{+}$ and Reelin ${ }^{+}$cells in the cortical hem did not appear to differ between Nestin-Cre;Tbr2 $2^{\text {flox/flox }}$ mutants and control mice at E14.5 (Fig. $2 A-A 3, B-B 3, C, C 1, D, D 1$ ). Likewise, proliferation of $\mathrm{p} 73^{+}$cells appeared normal in the hem of mutant mice. Indeed, the majority of $\mathrm{p} 73^{+}$cells in the cortical hem coexpressed PCNA at E14.5 in both controls (Fig. 2E-E3) and Nestin-Cre;Tbr2 $2^{\text {flox/flox }}$ mice (Fig. 2F-F3). These results suggest that Tbr2 is not required for the proliferation and generation of cortical hem-derived Cajal-Retzius cells.

At E15.5, Reelin ${ }^{+}$cells began to migrate in control mice concurrent with invagination of the pia, forming the presumptive HF

\section{$\leftarrow$}

(Figure legend continued.) $\boldsymbol{E}$, Transition of progenitor cells out of the SPZ occurs between P3-P5. $\boldsymbol{F}$, The SGZ neurogenic niche is established by P5-P7. G, G1, Tbr2 protein (red) is expressed in cells in the cortical hem $(\mathbf{C H})$ at E12.5 in control mice. $\boldsymbol{H}, \boldsymbol{H 1}$, Tbr2 protein is ablated in the cortical hem of mutant mice by E12.5. White dashed boxes in $\boldsymbol{G}$ and $\boldsymbol{H}$ represent areas shown at higher magnification in $\mathbf{G} \mathbf{1}$ and $\boldsymbol{H 1}$, respectively. $\mathbf{I}-\boldsymbol{L}$, Expression of $W n t 3 a$ and $W n t 5 a$, markers of the cortical hem, are present at approximately normal levels in Nestin-Cre; $T b r 2^{\text {flox/flox }}$ mice. $M, N, M 1, N 1$, Markers of DG granule neurons (NeuroD1, Prox1) are present in the primordial DG of mutant mice but are slightly reduced compared with controls as early as E14.5. Scale bars: $\mathbf{G}$, $100 \mu \mathrm{m} ; G 1,20 \mu \mathrm{m} ; I, 100 \mu \mathrm{m} ; M, 75 \mu \mathrm{m} ; M 1,15 \mu \mathrm{m}$.
(Figs. $1 B$ and Fig. $3 A, A 1$ ). Conversely, in Nestin-Cre;Tbr2 $2^{\text {flox/flox }}$ mice, initial invagination of the pial surface was delayed, resulting in a truncated $\mathrm{HF}$, and the developing DG failed to take on its characteristic semicircle shape (Fig. $3 \mathrm{~B}, \mathrm{B1}$ ). Consequently, the DG of Nestin-Cre;Tbr2 $2^{\text {flox/flox }}$ mice appeared to be rotated by $\sim 90^{\circ}$ compared with controls (Fig. 3, compare $A$ with $B$ ) at E15.5. By E16.5, invagination of the pial surface and concurrent migration of Cajal-Retzius cells into the HF were readily identifiable in control mice (Fig. 3D-D2). In controls, the majority of Reelin ${ }^{+}$ cells were observed in the HF, with a smaller population of these cells localized to the DMS (Fig. 3D1,D2). In Nestin-Cre; $\mathrm{Tbr} 2^{\text {flox/flox }}$ mice, the cumulative density of Reelin ${ }^{+}$cells in the hem, DMS, and DG did not appear to be significantly reduced compared with controls at E16.5, but ectopic accumulation of Reelin ${ }^{+}$cells was apparent in mutant mice (Fig. 3E-E2). Specifically, a substantial number of Reelin ${ }^{+}$Cajal-Retzius cells were observed in the DMS, and fewer Reelin ${ }^{+}$cells were observed in the HF (Fig. 3E-E2) of Nestin-Cre;Tbr $2^{\text {flox/flox }}$ mice, suggesting impaired migration of these cells to the developing DG in mutant animals. Likewise, the surface area of the HF was significantly reduced in Nestin-Cre;Tbr2 ${ }^{\text {flox/flox }}$ mice at E16.5 (Fig. 3C,E2) compared with controls (Fig. 3C,D2), and the DG of mutant mice appeared to be abnormally shaped (Fig. 3E,E2). Likely as a result of ectopic accumulation of Reelin ${ }^{+}$cells in the DMS, the density of Reelin $^{+}$cells populating the HF was significantly reduced in Nestin-Cre;Tbr $2^{\text {flox/flox }}$ mice at E16.5 (control $=1874 \pm 56$ cells/ $\mathrm{mm}^{2}$, Nestin-Cre;Tbr $2^{\text {flox } / \text { flox }}=1045 \pm 72$ cells $/ \mathrm{mm}^{2} ; t$ test $N=$ $3 ; p<0.01)$. By P3, very few Reelin ${ }^{+}$cells were observed in the DMS of control mice (Fig. 3F-F2), and the greatest concentration of Reelin ${ }^{+}$cells was observed in the HF. The surface area of the HF had increased in control mice at P3 compared with E16.5 as the result of continued growth of the DG (Fig. 3C,D,F). Decreased invagination of the pial surface persisted in P3 Nestin-Cre;Tbr $2^{\text {flox/flox }}$ mice as evidenced by the continued and significant reduction HF surface area in mutants (Fig. 3C, G, G2). Ectopic Reelin ${ }^{+}$cells remained concentrated in the DMS of mutant mice at P3 (Fig. 3G,G1). Whereas the greatest density of Reelin ${ }^{+}$cells in $\mathrm{P} 3$ control mice was observed in the region of the HF overlying the lateral tip of the suprapyramidal DG blade (Fig. $3 F$ ), Reelin ${ }^{+}$cells in P3 Nestin-Cre;Tbr ${ }^{\text {flox/flox }}$ mice were more diffusely dispersed throughout the entirety of the HF (Fig. $3 G$ ). As well, ectopic accumulation of Reelin ${ }^{+}$cells was observed at the tip of the developing DG in P3 Nestin-Cre;Tbr2 ${ }^{\text {flox/flox }}$ mice (Fig. $3 G, G 2)$, further supporting abnormal migration of Cajal-Retzius cells in mutant animals.

\section{Formation of the transhilar glial scaffold is aberrant in Nestin-Cre; Tbr $2^{\text {flox/flox }}$ mice}

During the course of early DG development, $\mathrm{Blbp}^{+}$radial glia migrate from the dentate ventricular zone (VZ) to the fimbriodentate junction (FDJ), a transitional region bridging the fimbria and the developing DG (Figs. $1 D$ and 4A,A1) (Li et al., 2009). These Blbp ${ }^{+}$cells contribute to the formation of the transhilar radial glial scaffold, a structure that guides migrating progenitors and neuroblasts to the developing DG (Figs. $1 D$ and $4 A, A 1$ ) (Frotscher et al., 2003; Li et al., 2009). Later in DG development, $\mathrm{Blbp}^{+}$cells migrate across the hilus and, ultimately, take up residence in the HF (Figs. $1 D$ and $4 A 1, C, C 1$ ) (Li et al., 2009). In E16.5 control mice, Blbp ${ }^{+}$radial glia were observed exiting the FDJ and migrating through the hilus (Fig. 4A,A1). These cells typically did not coexpress Tbr2 protein (data not shown). Some $\mathrm{Blbp}^{+}$cells extended radial processes across the hilus in control mice (Fig. 4A1). Concurrent with ectopic accumulation of Ree- 


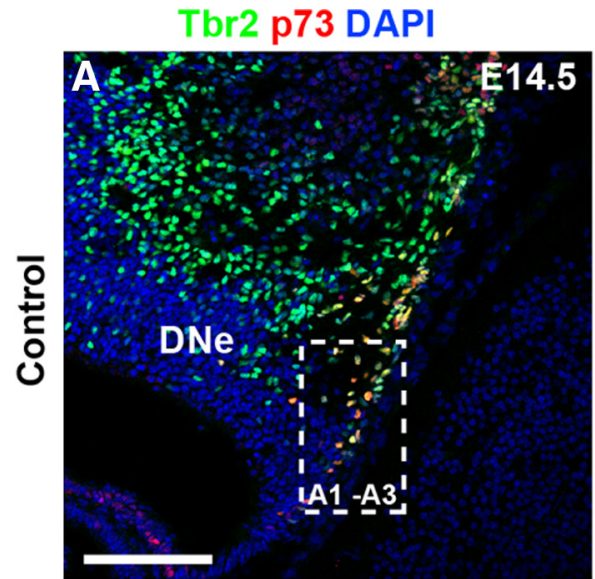

Tbr2 DAPI
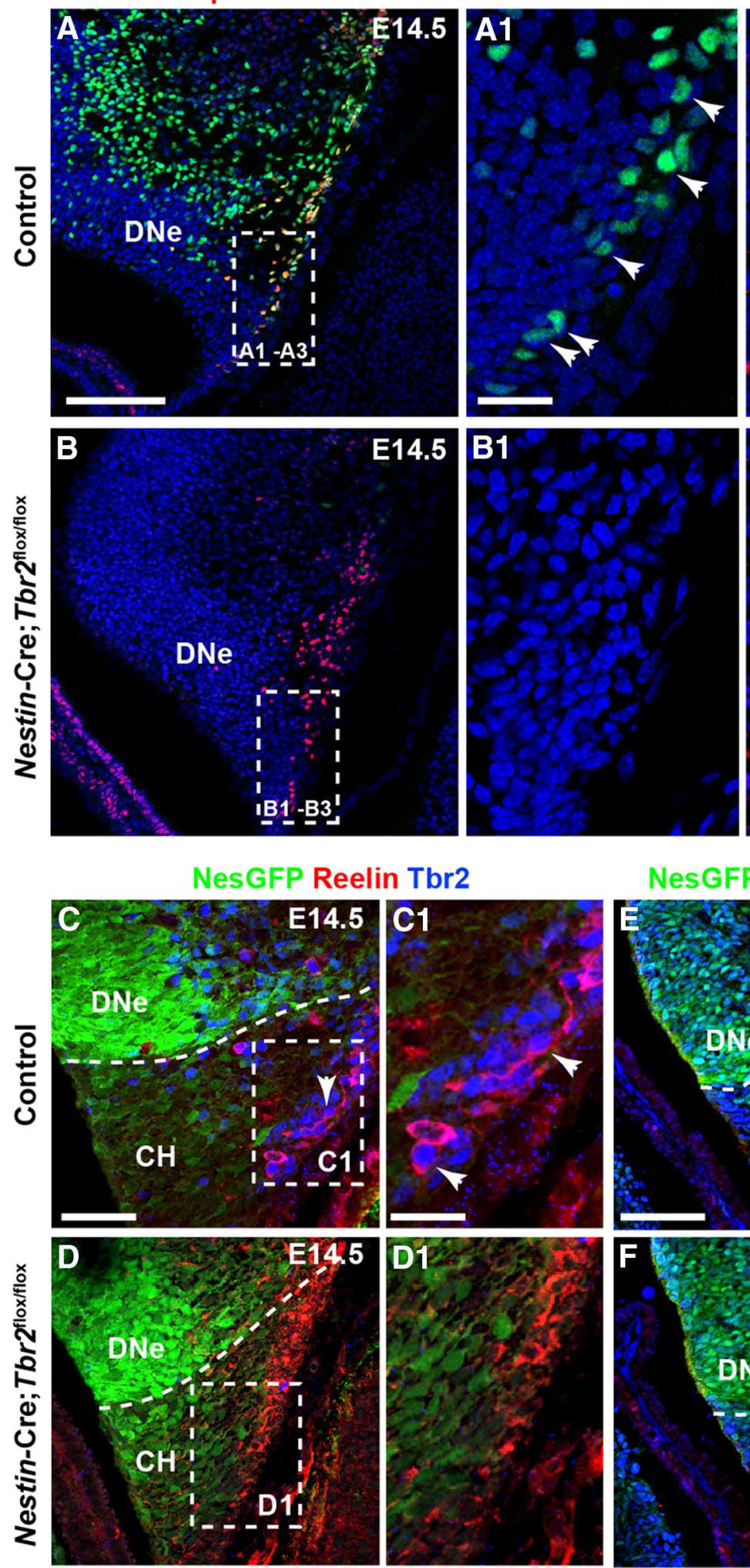

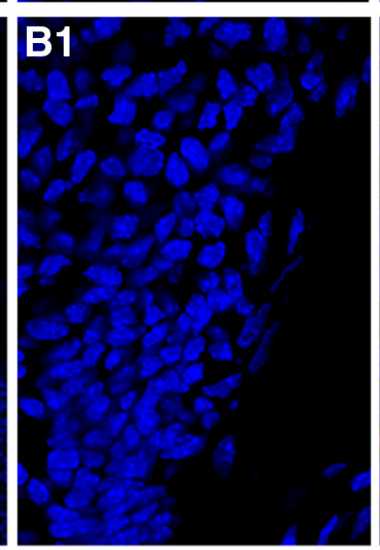

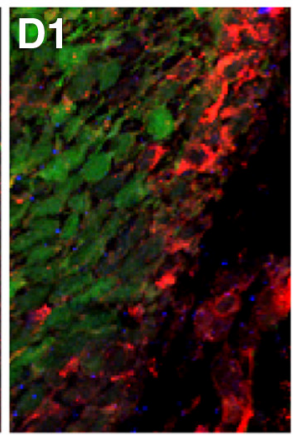

Tbr2 p73 DAPI
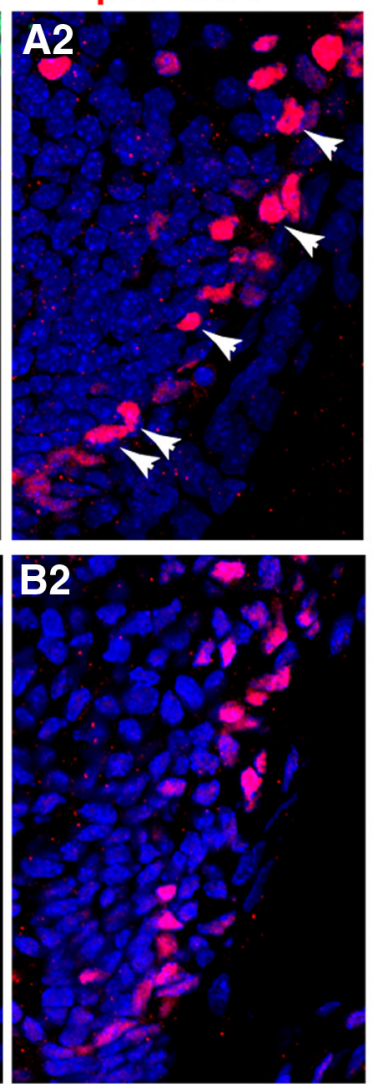
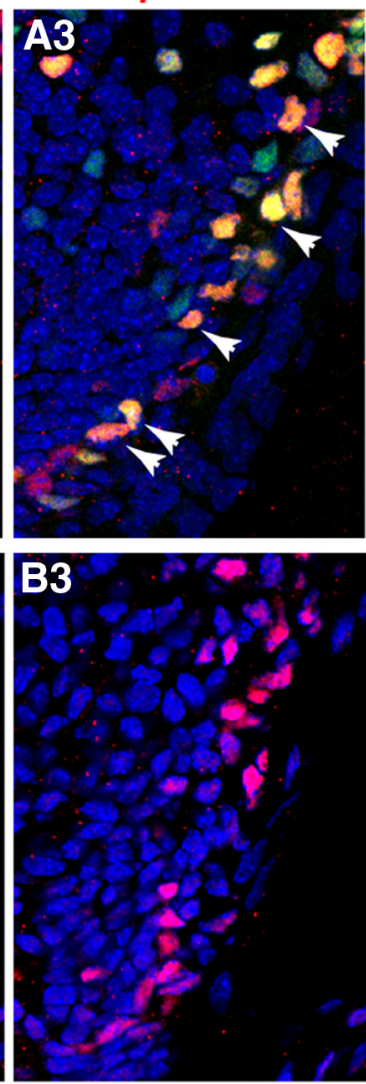

\section{NesGFP p73 PCNA}

\section{p73}

PCNA Merge
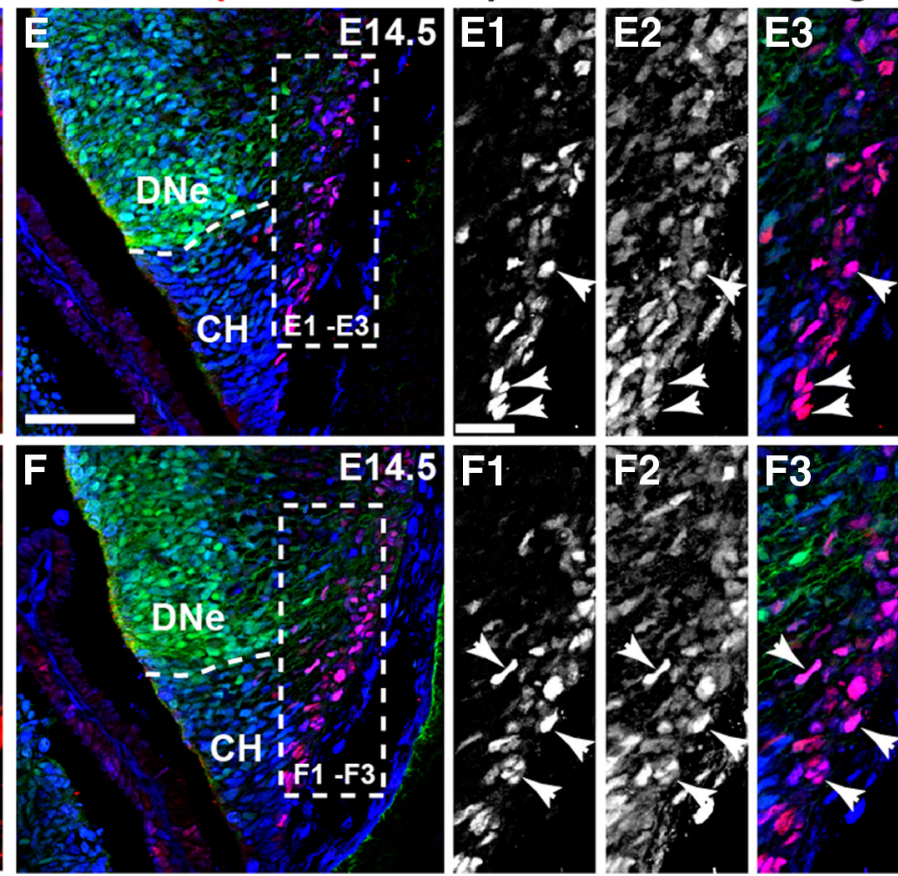

Figure 2. Tbr2 expression is ablated in cortical hem-derived Cajal-Retzius cells in Nestin-Cre; $T b r 2^{\text {floxflox }}$ mice. A-A3, At E14.5, the majority of p $733^{+}$Cajal-Retzius cells in the cortical hem (CH) coexpress Tbr2 (arrows). $\boldsymbol{B}$ - B3, p73 expression is maintained in the CH of Nestin-Cre;Tbr2 ${ }^{\text {floxfflox }}$ mice at E14.5; however, Tbr2 protein is absent from these cells (B2, B3). C-D1, Similarly, Tbr2 ${ }^{+}$cells coexpress Reelin in the CH of control mice at E14.5, whereas Tbr2 protein is absent from Reelin ${ }^{+}$Cajal-Retzius cells in Nestin-Cre; $T b r 2$ floxfflox mice (D1). Regardless, the density of Cajal-Retzius cells

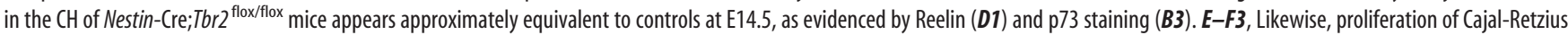
cells in the $\mathrm{CH}$ appears unaffected by ablation of Tbr2, as an approximately equivalent number of p $73^{+}$cells coexpress $\mathrm{PCNA}$ (arrows) in controls (E1-E3) and Nestin-Cre; $7 b r 2^{\text {floxfflox }}$ mice (F1-F3). Scale bars: $A, 150 \mu \mathrm{m} ; A 1,50 \mu \mathrm{m} ; C, 100 \mu \mathrm{m} ; C 1,30 \mu \mathrm{m} ; E, 100 \mu \mathrm{m} ; E 1,15 \mu \mathrm{m}$. Regions delineated by dashed white boxes are shown in higher magnification in their respective adjacent panels. 

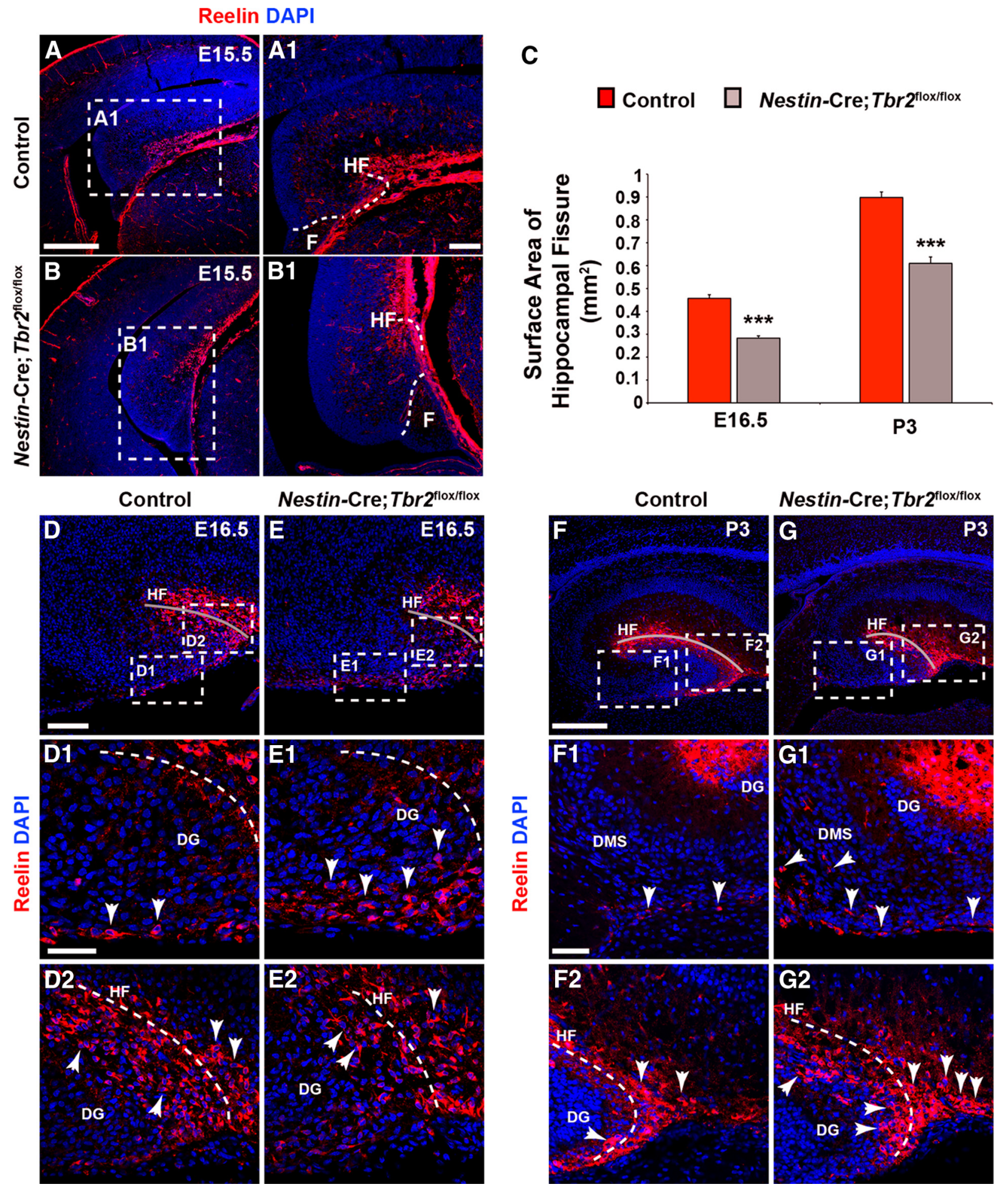

Figure 3. Rotation of the hippocampus and formation of the $\mathrm{HF}$ are abnormal in Nestin-Cre; $T b r 2^{\text {flox/flox }}$ mice. $\boldsymbol{A}, \boldsymbol{A} \mathbf{1}$, In control mice, invagination of the pial surface to form the $\mathrm{HF}$ occurs concurrent with rotation of the developing hippocampus. $B, B 1$, In Nestin-Cre; $T b r 2^{\text {flox/flox }}$ mice, rotation of the hippocampus is impaired, such that the DG appears to be rotated $90^{\circ}$ in mutant mice compared with controls (compare $\boldsymbol{A}$ and $\boldsymbol{B}$ ). $\boldsymbol{B}, \boldsymbol{B} \mathbf{1}$, As well, invagination of the pial surface is delayed in mutant mice, resulting in a reduction in the size of the HF. C, Consistent with delayed invagination of the pial surface in Nestin-Cre; $T b r 2^{\text {flox }}{ }^{\text {fllox }}$ mice, the surface area of the HF is persistently and significantly reduced in mutant mice (ANOVA,N $\left.=3, p<0.001\right)$. Graphs represent the mean \pm SEM. ${ }^{* *} p<0.01 .{ }^{* * *} p<0.001$. D-D2, By E16.5, the majority of Reelin ${ }^{+}$Cajal-Retzius cells are localized to the HF (gray line) in control mice (D2), and a smaller population of these cells can be seen in the DMS. $\boldsymbol{E}-\mathbf{E 2}$, In contrast, the DMS is rich in Reelin ${ }^{+}$Cajal-Retzius cells in Nestin-Cre; Tbr ${ }^{\text {flox/flox }}$ mice, and there are fewer of these cells located in the HF in mutant mice, suggesting impaired migration and ectopic localization of these cells in mutants. The reduction in HF surface area is also evident in mutant mice (compare gray lines in $\boldsymbol{D}, \boldsymbol{E}$ vs $\mathbf{D 2}, \mathbf{E 2}$ ). $\boldsymbol{F}$ - F2, By P3, very few Reelin ${ }^{+}$Cajal-Retzius cells remain in the DMS in control mice (arrows), and the bulk of these cells are located in the HF (F2), which has increased in surface area with continued growth of the DG compared with controls at E16.5. G-G2, However, in Nestin-Cre;Tbr2 ${ }^{\text {flox/flox }}$ mice, ectopic Reelin ${ }^{+}$cells can been seen in the DMS (G1, arrows) at P3, suggesting impaired migration of these cells to the HF. G2, In mutant mice, there is also an increased concentration of Reelin ${ }^{+}$cells at the tip of the DG arrows compared with controls $(\boldsymbol{F}, \boldsymbol{F} 2)$, further supporting ectopic localization of Cajal-Retzius cells in Nestin-Cre; $T b r 2^{\text {flox flox }}$ mice. Scale bars: $\boldsymbol{A}, 200 \mu \mathrm{m} ; \boldsymbol{A 1}, 50 \mu \mathrm{m} ; \boldsymbol{D}, 175 \mu \mathrm{m} ; \mathbf{D 1}, 50 \mu \mathrm{m} ; \boldsymbol{F}, 175 \mu \mathrm{m} ; \boldsymbol{F 1}, 75 \mu \mathrm{m}$. Regions delineated by dashed white boxes are shown in higher magnification in their respective adjacent panels. $\mathbf{D}-\mathbf{G}$, Gray lines highlight the $\mathrm{HF}$ in each panel. 

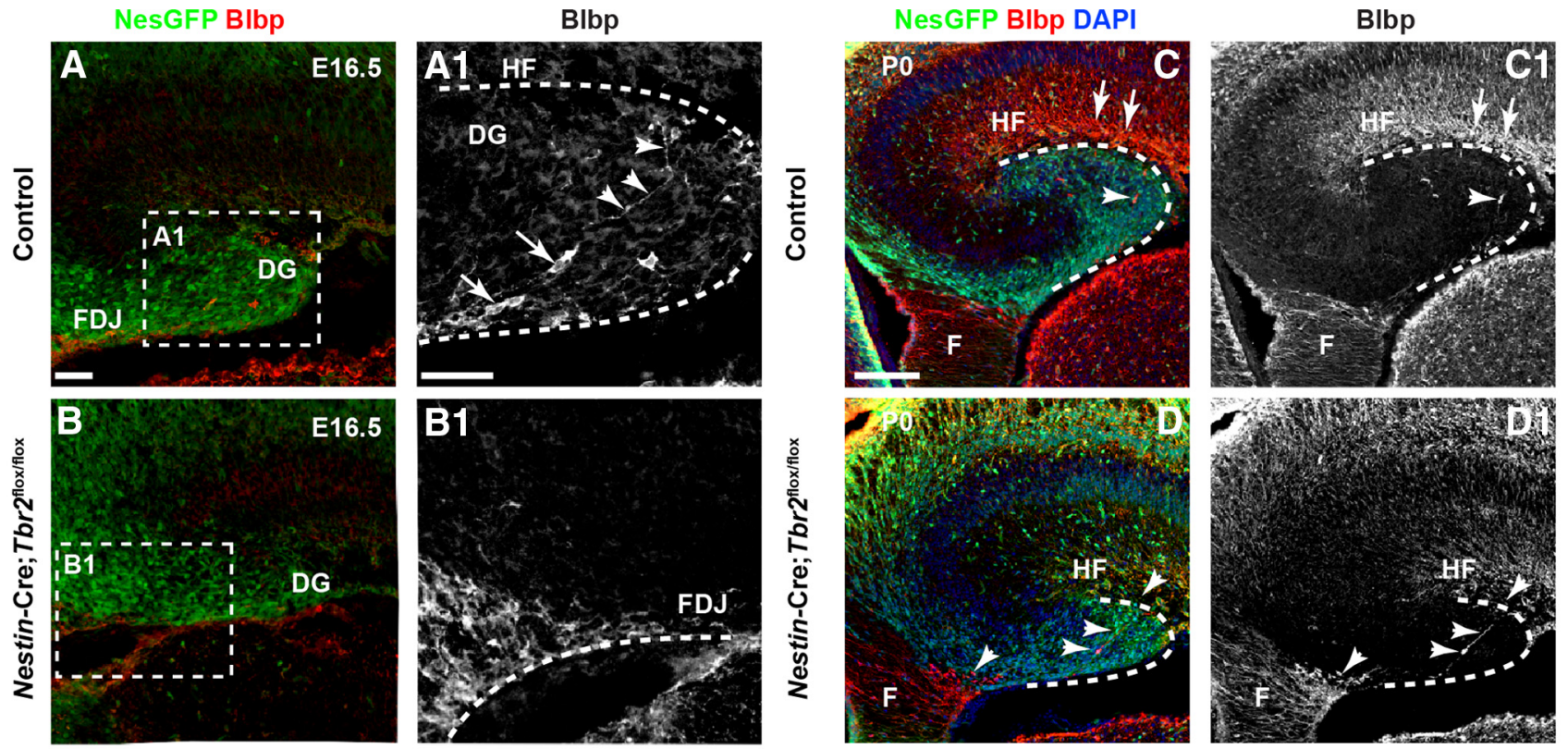

Control

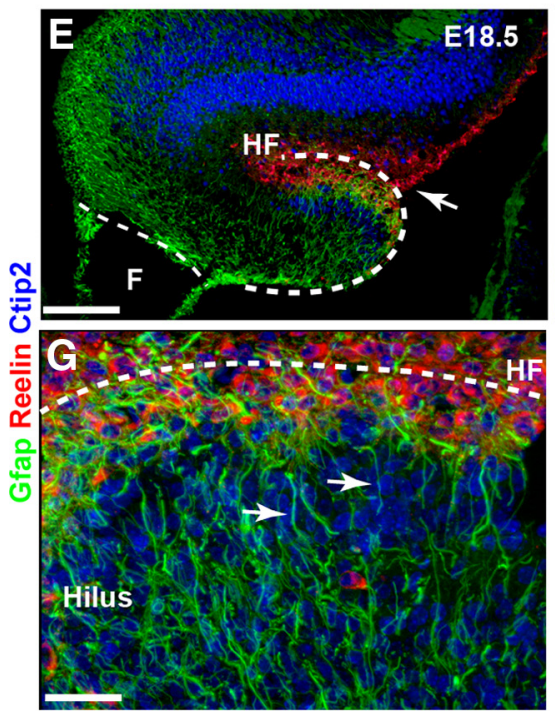

Nestin-Cre; Tbr2flox/flox

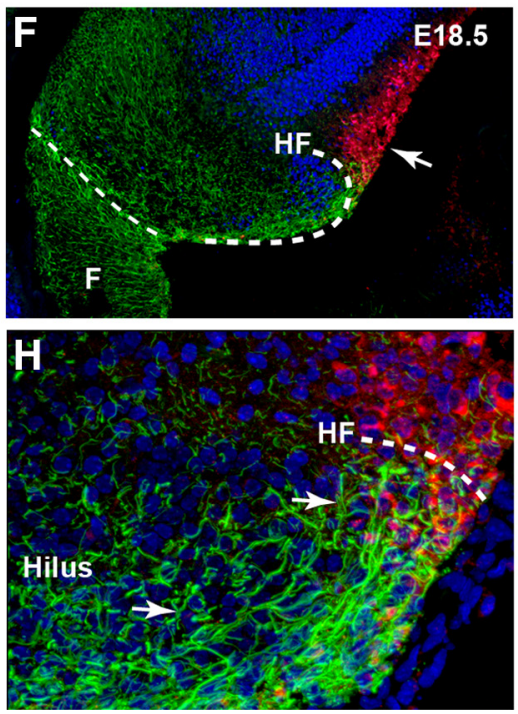

Control

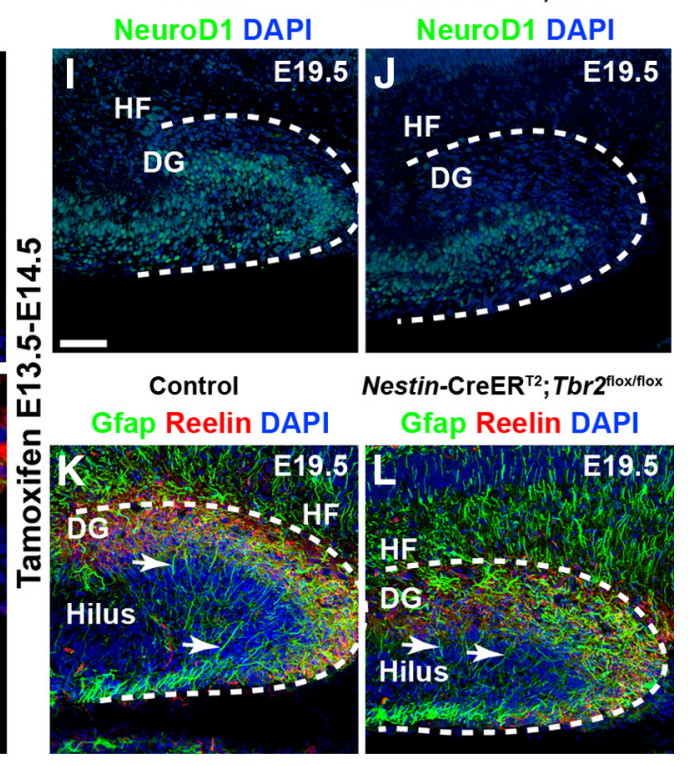

Figure 4. Development of the transhilar radial glial scaffold is perturbed after ablation of $T b r 2 . A, A 1$, In E16.5 control mice, Blbp ${ }^{+}$radial glia exit the dentate VZ and migrate to the $H F$ to take up residence in the dentate marginal zone. They can be seen exiting the FDJ region and migrating across the hilus ( $\boldsymbol{A} 1$, cell bodies are marked by arrows and associated processes by arrowheads). $B, B 1$, Migration of Blbp ${ }^{+}$cells is delayed in Nestin-Cre; $T b r 2^{\text {flox/flox }}$ mice, and accumulation of Blbp ${ }^{+}$cells is apparent in the fimbria and FDJ. Regions delineated by dashed white boxes are shown in higher magnification in their respective adjacent panels $(\boldsymbol{A 1}, \mathbf{B 1}) . \boldsymbol{C}, \mathbf{C} 1, \mathrm{By} \mathrm{PO}, \mathrm{Blbp}{ }^{+}$cell migration is essentially complete in control mice, and enrichment of Blbp ${ }^{+}$processes is apparent in the HF. D, D1, In Nestin-Cre; Tbr ${ }^{\text {flox/flox }}$ mice (arrows), Blbp ${ }^{+}$cells remain concentrated in the fimbria and FDJ and only rarely can be seen migrating to the HF (arrowheads). $\boldsymbol{E}-\boldsymbol{H}$, Gfap ${ }^{+}$processes making up the transhilar glial scaffold are aberrant in Nestin-Cre; $T b r 2^{\text {flox/flox }}$ mice. In control mice $(\boldsymbol{E}, \boldsymbol{G}), \mathrm{Gfap}^{+}$processes exhibit clear radial orientation across the hilus, whereas $\mathrm{Gfap}{ }^{+}$processes are oriented either randomly or toward the reduced $\mathrm{HF}$ where Reelin ${ }^{+}$Cajal-Retzius cells are located in Nestin-Cre; $\mathrm{Tbr} 2^{\text {flox/flox }}$ mice $(\boldsymbol{F}, \boldsymbol{H}$, arrows). These processes do not exhibit the clear radial

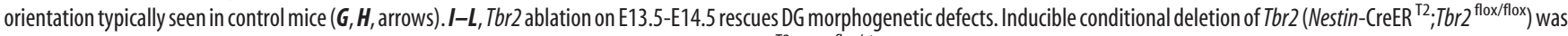
achieved by treating mice with tamoxifen on E13.5 and E14.5. Control mice were Nestin-CreER ${ }^{\mathrm{T} 2} ; \mathrm{Tbr} 2^{\mathrm{flox} /+}$. $I, J$, Consistent with the known role of Tbr2 in regulating granule cell neurogenesis, NeuroD1 ${ }^{+}$neuroblasts are reduced in the developing DG of Nestin-CreER ${ }^{\mathrm{T2}} ; \mathrm{Tbr}_{2}{ }^{\text {flox/flox }}$ mice, resulting in a decrease in the overall size of the DG $(\boldsymbol{J})$ at E19.5. However, the HF is approximately the same size in controls $(\boldsymbol{K})$ and Nestin-CreER ${ }^{T 2} ; T_{b r} 2^{\text {flox/flox }}$ mice $(\boldsymbol{L})$. Reelin ${ }^{+}$Cajal-Retzius cells are abundant in the dentate marginal zone adjacent to the $H F$ in both controls $(\boldsymbol{K})$ and Nestin-CreER ${ }^{T 2} ; T_{b r} 2^{\text {flox/flox }}$ mice $(\boldsymbol{L})$, and $G$ fap ${ }^{+}$processes are radially oriented across the hilus in both groups $(\boldsymbol{K}, \boldsymbol{L}$, arrows) consistent with normal development of the transhilar radial scaffold. Scale bars: $\boldsymbol{A}, 50 \mu \mathrm{m} ; \boldsymbol{A} \mathbf{1}, 30 \mu \mathrm{m} ; \boldsymbol{C}, 75 \mu \mathrm{m} ; \boldsymbol{E}, 100 \mu \mathrm{m} ; \mathbf{G}, 30 \mu \mathrm{m} ; \mathbf{I}, 50 \mu \mathrm{m}$.

$\operatorname{lin}^{+}$cells on E16.5, Blbp ${ }^{+}$radial glial exiting the dentate VZ were delayed in their migration to the HF in Nestin-Cre;Tbr $2^{\text {flox/flox }}$ animals (Fig. 4B,B1). Specifically, in mutant mice, the majority of Blbp ${ }^{+}$cells remained in the fimbria and FDJ at E16.5 (Fig. 4B1). By P0, Blbp ${ }^{+}$cells were enriched in the HF of control mice, and few remained in the either the fimbria or FDJ (Fig. $4 C, C 1$ ). In
Nestin-Cre; $T b r 2^{\text {flox/flox }}$ mice, many Blbp ${ }^{+}$cells remained in the fimbria and FDJ on P0, and few cells were observed migrating through the hilus (Fig. 4D,D1). As a result, the HF was largely devoid of Blbp ${ }^{+}$cells in mutant mice at P0 (Fig. 4D,D1). Accordingly, Gfap immunostaining at E18.5 clearly illustrated perturbed transhilar glial scaffold development in Nestin-Cre;Tbr $2^{\text {flox/flox }}$ 
mice (Fig. 4E-H). In controls, Gfap ${ }^{+}$processes were enriched in the $\mathrm{HF}$ adjacent to Reelin ${ }^{+}$Cajal-Retzius cells, and radially oriented processes were also observed extending through the hilus (Fig. 4E,G). In Nestin-Cre;Tbr2 ${ }^{\text {flox/flox }}$ mice, Gfap ${ }^{+}$processes were sparse in the reduced $\mathrm{HF}$, and the remaining processes were oriented randomly across the hilus, failing to obtain the characteristic radial orientation of the transhilar radial glial scaffold (Fig. $4 F, H)$.

\section{Defects in early DG morphogenesis can be rescued by temporally restricting $T b r 2$ ablation}

Given that Reelin ${ }^{+}$Cajal-Retzius cells are critical orchestrators of early DG morphogenesis, we hypothesized that failure to properly form the HF and transhilar radial glial scaffold occurred predominantly as a result of defects in Cajal-Retzius cell development and migration in Nestin-Cre; Tbr $2^{\text {flox/flox }}$ mice. To test this hypothesis, we crossed an inducible Nestin-CreER ${ }^{\mathrm{T} 2}$ Cre-driver with the $T b r 2^{\text {flox }}$ conditional allele and treated pregnant females with tamoxifen on E13.5 and E14.5. By doing so, we restrictedTbr2 conditional deletion to later embryonic stages after the bulk of Cajal-Retzius cells were produced in the cortical hem. Therefore, the majority of early generated Cajal-Retzius cells should be spared from Tbr2 knock-out in this model. Interestingly, reduced DG granule neuron production was readily apparent in Nestin-CreER ${ }^{\mathrm{T} 2} ;$ Tbr $2^{\text {flox/flox }}$ mice by E19.5, as illustrated by decreased numbers of NeuroD $1^{+}$cells in mutant animals (Fig. $4 I, J)$, consistent with the role of Tbr2 in regulating DG neurogenesis (Hodge et al., 2012). Accordingly, the developing DG appeared reduced in size (Fig. $4 I, J$ ). However, the length and surface area of the HF appeared to be equivalent to age-matched controls in Nestin-CreER ${ }^{\mathrm{T} 2}$; Tbr $2^{\text {flox/flox }}$ mice (Fig. $4 K, L$ ), suggesting that invagination of the pia occurred as usual when Tbr2 was ablated at later developmental stages. Strikingly, similar densities of Reelin ${ }^{+}$Cajal-Retzius cells populated the HF in both control and Nestin-CreER ${ }^{\mathrm{T} 2} ; \mathrm{Tbr} 2^{\text {flox/flox }}$ mice, and there was no evidence of ectopic accumulation of Reelin ${ }^{+}$cells in mutant animals, suggesting that normal migration of Cajal-Retzius cells occurred concurrent with invagination of the pia in Nestin-CreER ${ }^{\mathrm{T} 2} ; \mathrm{Tbr} 2^{\text {flox/flox }}$ mice (Fig. $4 K, L$ ). Accordingly, we observed an enrichment of Gfap ${ }^{+}$processes in the HF in both control and Nestin-CreER ${ }^{\mathrm{T} 2} ; \mathrm{Tbr} 2^{\text {flox/flox }}$ mice, and radially oriented Gfap ${ }^{+}$processes extending through the hilus were apparent in both groups consistent with normal formation of the transhilar radial glial scaffold (Fig. $4 K, L$ ). These results suggest that restricting Tbr2 knock-out to later embryonic development largely abrogated defects in DG morphogenesis, supporting the notion that these effects were principally dependent on proper localization of Reelin ${ }^{+}$CR cells to the HF.

\section{Tbr2 ablation results in aberrant neurogenesis during DG development}

Previous work from our laboratory established that Tbr2 expression in INPs was required for granule cell neurogenesis in the developing and adult DG (Hodge et al., 2012). To confirm these results, we examined expression of Tbr2 in the E16.5 DG (Fig. $5 A-B 4)$. Similar to what we have reported in the adult DG (Hodge et al., 2008, 2012), we found that a subset of Tbr2 ${ }^{+}$cells in the dentate VZ coexpressed the NSC marker Sox2 (Fig. 5A1A3), suggesting that Tbr2 is expressed during the transition from NSC to INP in the developing DG as it is in the adult DG (Hodge et al., 2012). A small cohort of cells coexpressing Sox 2 and Tbr2 was also apparent in the DMS, consistent with extensive migration of NSCs and INPs to the developing DG (Fig. 5B1-B4).
Unlike Tbr2 and Sox2, Prox ${ }^{+}$cells were largely confined to the developing DG, although scattered Prox ${ }^{+}$cells were observed in the DMS at E16.5 (Fig. 5A,B1-B4). Coexpression of Sox2 and Prox1 was extremely rare at E16.5 (Fig. $5 B 1-B 4$ ). Tbr $2^{+} /$Prox $1^{+}$ cells were observed in the DMS (Fig. 5B1-B4). However, these $\mathrm{Tbr}^{+} /$Prox $^{+}$cells were rare. The majority of Tbr $2^{+}$cells in the DMS/DG at E16.5 were Prox1-negative. Likewise, most Prox1 ${ }^{+}$ cells did not coexpress Tbr2 under normal circumstances (Fig. 5B1-B4).

To determine whether Tbr2 was required for granule neurogenesis in the developing DG, we examined the expression of several granule neuron markers on E16.5 (Fig. 5C-F). At this age, new granule neuroblasts, marked by their expression of the transcription factors NeuroD1 and Prox1 (Liu et al., 2000; Pleasure et al., 2000; Schwab et al., 2000; Lavado and Oliver, 2007), were present predominantly in the forming upper blade of the DG in controls (Fig. $5 A, C, E$ ), although NeuroD $1^{+}$cells were also present in the developing hippocampal CA fields consistent with expression of NeuroD1 in this lineage (Pleasure et al., 2000). Interestingly, previous work suggested that granule cell generation is drastically reduced after Tbr2 ablation despite increased proliferation of Sox ${ }^{+}$NSCs (Hodge et al., 2012). However, when we examined very early stages of DG development in Nestin-Cre; Tbr $2^{\text {flox/flox }}$ mice, we found that increased numbers of NeuroD $1^{+} / \operatorname{Prox}{ }^{+}$neuroblasts were present along the extent of the DMS in mutants (Fig. 5D-F), in contrast to the decrease in NeuroD $1{ }^{+}$neuroblasts we observed when later stages of DG development (P3) were examined in Nestin-Cre;Tbr2 $2^{\text {flox/flox }}$ animals (Fig. 5P) (Hodge et al., 2012). As well, the DMS appeared to be expanded in Nestin-Cre;Tbr $2^{\text {flox/flox }}$ mice, and both NeuroD1 ${ }^{+}$and Prox ${ }^{+}$cells were widely dispersed throughout the enlarged DMS in mutants (Fig. 5D,F), well outside of the compartments they were confined to in age-matched controls (Fig. $5 C, E)$. Quantification of Prox $1^{+}$neuroblasts at E16.5 revealed a significant increase in Prox ${ }^{+}$cells $/ \mathrm{mm}^{2}$ in mutants (control $=$ $753 \pm 167$ cells $/ \mathrm{mm}^{2}$, Nestin-Cre;Tbr $2^{\text {flox/flox }}=2750 \pm 349$ cells/ $\mathrm{mm}^{2} ; 266 \%$ increase; $t$ test; $\left.p<0.01\right)$. Increased neurogenesis was confirmed in Nestin-Cre;Tbr $2^{\text {flox/flox }}$ mice using a BrdU pulse-chase experiment where BrdU was administered on E15.5 and embryos were collected on E17.5 (Fig. $5 K-L 1$ ). Relatively few $(9.24 \pm 0.29 \%) \mathrm{BrdU}^{+}$cells colabeled with Proxl in control embryos (Fig. $5 K, K 1$ ). However, this number increased significantly in Nestin-Cre;Tbr $2^{\text {flox/flox }}$ animals to $43.15 \pm 5.65 \%$ of total $\mathrm{BrdU}^{+}$cells ( $t$ test; $p<0.05 ; N=2$; Fig. $5 L, L 1$, arrows), suggesting that more Prox ${ }^{+}$neuroblasts were generated in Nestin-Cre;Tbr $2^{\text {flox/flox }}$ mice than in controls between E15.5 and E17.5.

To characterize these early generated neuroblasts further, we examined expression of several NSC markers in these cells, as we had previously shown that these markers were also upregulated in Nestin-Cre;Tbr $2^{\text {flox/flox }}$ mice at E16.5 (Hodge et al., 2012). Interestingly, we found that the proportion of Prox $1^{+}$cells that were proliferating in the DMS and DG appeared to be increased in Nestin-Cre;Tbr $2^{\text {flox/flox }}$ mice at E16.5 (Fig. 5G-H3). In E16.5 controls, very few Prox ${ }^{+}$cells coexpressed PCNA (Fig. 5G-G3), whereas Prox ${ }^{+} / \mathrm{PCNA}^{+}$cells were readily apparent in the DMS in Nestin-Cre; Tbr $2^{\text {flox/flox }}$ animals (Fig. $5 H-H 3$ ). As well, many Prox $1^{+}$neuroblasts aberrantly expressed markers of NSCs, including Sox2 and Nestin-GFP (Fig. 5I-J3) in Nestin-Cre; $\mathrm{Tbr} 2^{\text {flox/flox }}$ mice. Increased numbers of Sox $2^{+} / \mathrm{Prox}{ }^{+}$cells were observed throughout the DMS and in the developing DG of mutant mice (Fig. 5J-J3). In Nestin-Cre;Tbr $2^{\text {flox/flox }}$ animals, these Sox $2^{+} /$Prox $1^{+}$cells appeared to express low levels of Prox1 (Fig. 

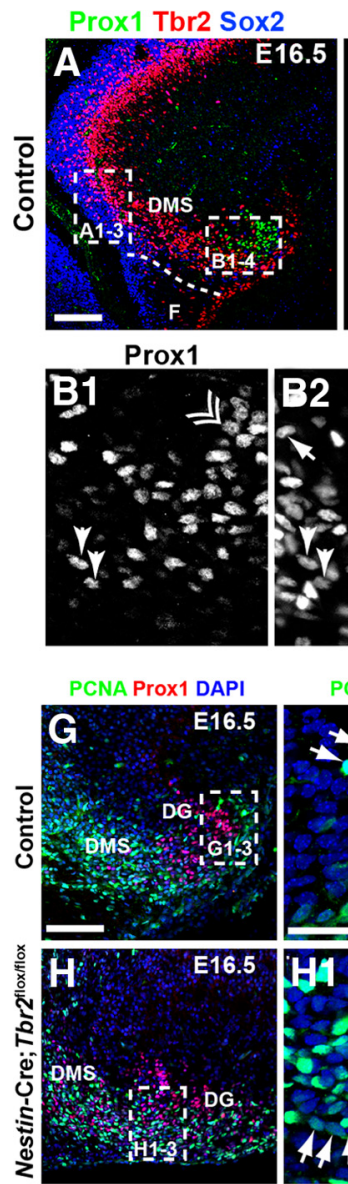

Prox1 BrdU
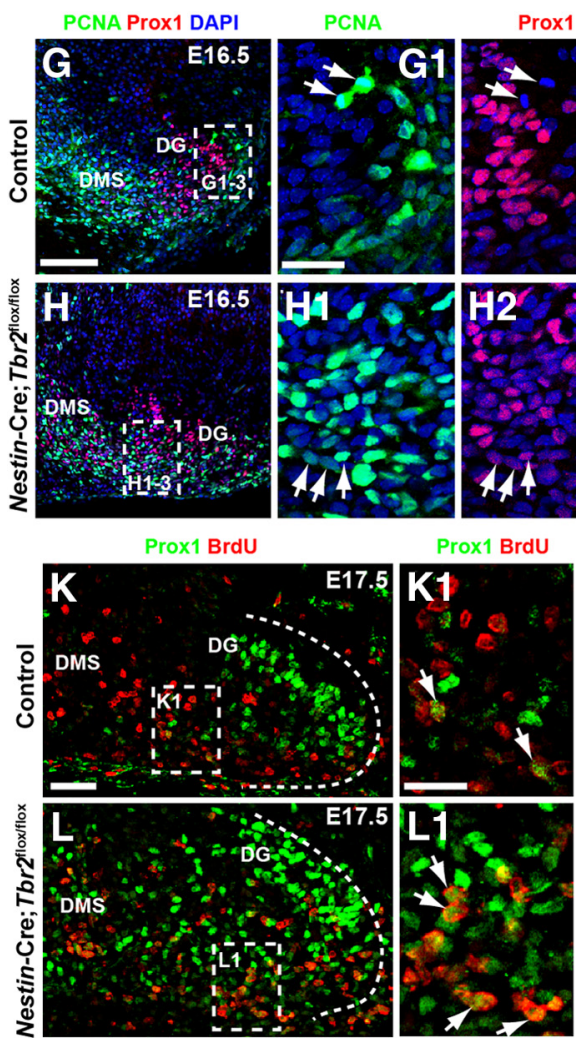

Control
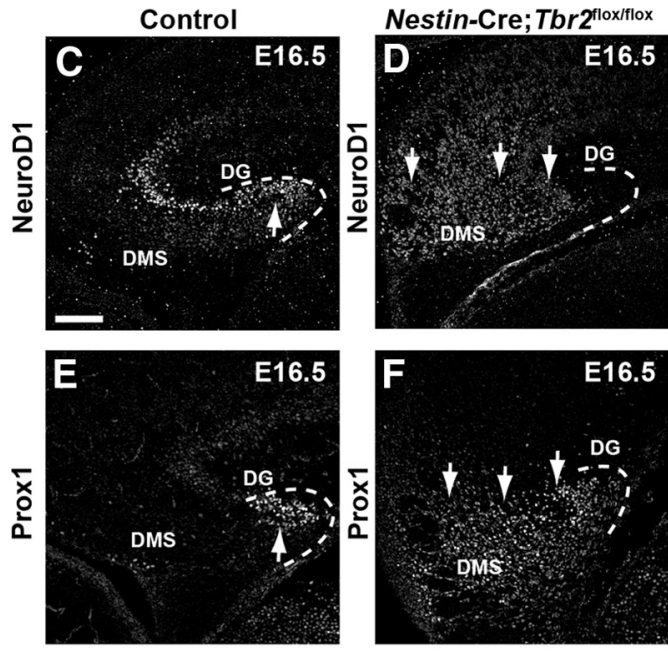

Sox2
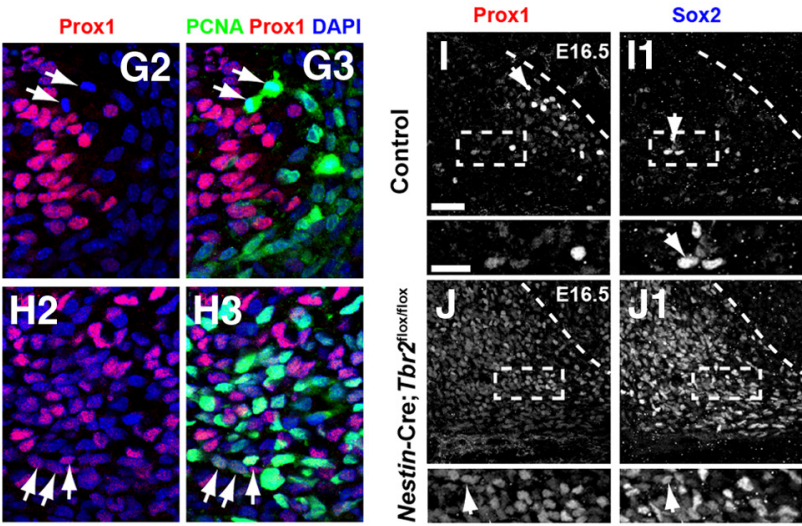

Prox1 Sox2 NesGFP
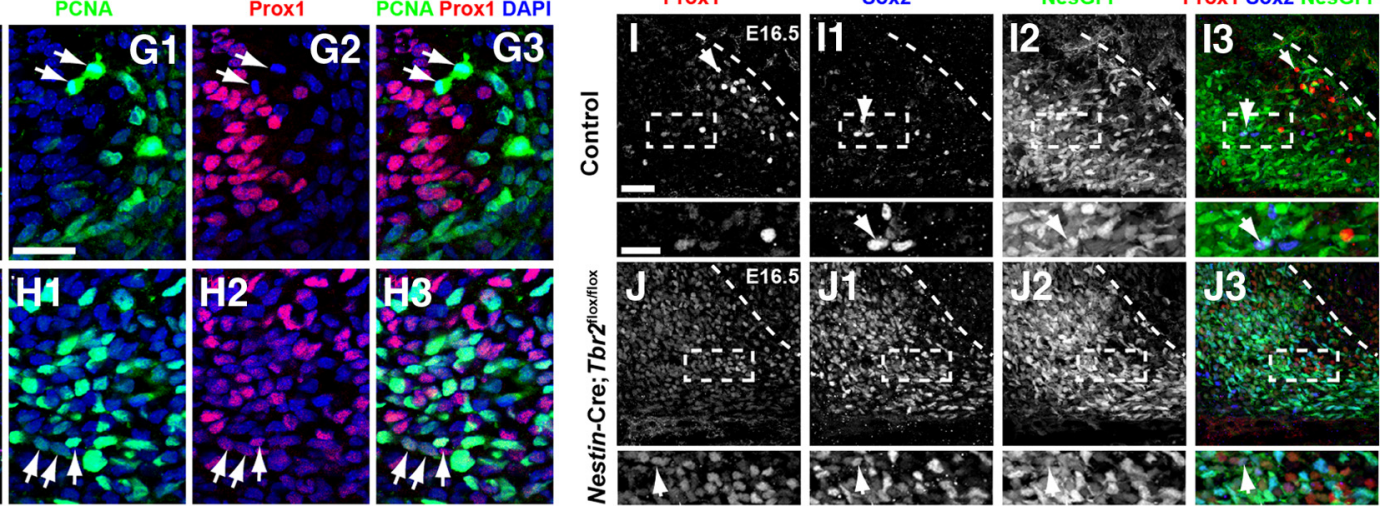
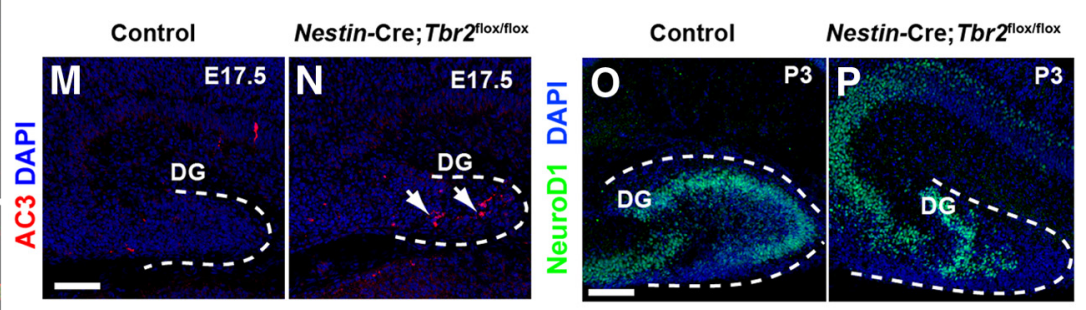

Figure 5. Premature granule cell neurogenesis is apparent in Nestin-Cre; Tbr ${ }^{\text {flox/flox }}$ mice. $\boldsymbol{A}-\mathbf{A 3}$, In control mice, Sox2 and Tbr2 are coexpressed in a subset of cells (arrows) in the dentate VZ, whereas Prox1 is not expressed in this region but rather is restricted to the DMS and developing DG $(\boldsymbol{A})$. However, Sox $2^{+} / \mathrm{Tbr}^{+}$cells represent a relatively minor fraction of the total Sox2 ${ }^{+}$ population, consistent with the notion that Sox2 is predominantly expressed in NSCs, whereas Tbr2 is largely restricted to INPs (A1-A3). B1-B4, Within the DMS, Tbr2 and Sox2 continue to be coexpressed in a subset of cells, and these cells are Prox1-negative (arrows). However, coexpression of Tbr2 and Prox 1 is apparent in a small subset of Tbr2 ${ }^{+}$cells, but these Tbr2 ${ }^{+} /$Prox ${ }^{+}{ }^{+}$cells are Sox2-negative (arrowheads). Prox1 and Sox2 coexpression is very rare in control animals at E16.5, consistent with downregulation of Sox2 during neuronal differentiation. Accordingly, most Prox ${ }^{+}$cells do not coexpress Sox2 or Tbr2 (double arrowhead). C, In control mice, NeuroD1 ${ }^{+}$neuroblasts are present in the forming suprapyramidal blade of the DG (arrow) and in the hippocampal CA3 field. Only scattered NeuroD1 ${ }^{+}$cells are present in the DMS in controls. D, In Nestin-Cre;Tbr ${ }^{\text {flox/flox }}$ mice, numerous NeuroD ${ }^{+}$cells are present in the DMS, which appears to be expanded compared with controls, but relatively few are in the DG itself. $\boldsymbol{E}$, Prox1 protein is also mostly restricted to the forming DG in control mice, whereas Prox 1 is expressed extensively in the expanded DMS of Nestin-Cre; Tbr ${ }^{\text {flox/flox }}$ mice, indicative of an early burst of neurogenesis in mutant animals at E16.5 (F). G-G3, In control mice, Prox $1^{+}$neuroblasts rarely proliferate as evidenced by the scarcity of Prox ${ }^{+} / \mathrm{PCNA}{ }^{+}$cells in these mice. Arrows illustrate

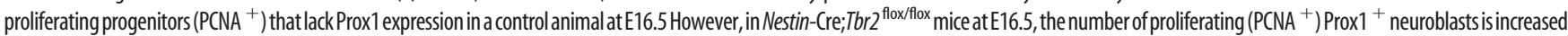
(H1-H3, arrows) within the expanded DMS and developing DG. Although PCNA ${ }^{+} /$Prox ${ }^{+}{ }^{+}$cells appear to express Prox1 at low levels, these cells still represent a minority of the total population of Prox ${ }^{+}$ neuroblasts in mutant mice $(\boldsymbol{H 1}-\boldsymbol{H 3})$. I-I3, In control mice at E16.5, Prox $1^{+}$neuroblasts very rarely coexpress the NSC markers Sox2 and Nestin-GFP (NesGFP), consistent with downregulation of these NSC markers in neuroblasts. J-J3, Conversely, in Nestin-Cre;Tbr2 ${ }^{\text {flox/flox }}$ mice, there is extensive, unusual colocalization of Prox1, Sox2, and Nestin-GFP in the DG. Similar to our observations of Prox ${ }^{+} /$PCNA ${ }^{+}$cells in mutant mice $(\boldsymbol{H 1} \mathbf{H} \mathbf{H})$, Prox1 appears to be expressed at low levels in these mutant Prox $1^{+} /$Sox2 ${ }^{+} /$NesGFP $^{+}$cells (J-J3). $\boldsymbol{K}-\mathbf{L 1}$, BrdU pulse-chase labeling (BrdU injected on E15.5. with embry0 collection on E17.5) shows that the percentage of Prox $1^{+} /$BrdU $^{+}$cells is increased in Nestin-Cre; Tbr ${ }^{\text {flox/flox }}$ mice $(\boldsymbol{L}, \mathbf{L} \mathbf{1}$, arrows) compared with controls $(\boldsymbol{K}, \boldsymbol{K} \mathbf{1}$, arrows), confirming premature neurogenesis in mutant mice during embryonic DG development. $\boldsymbol{M}, \boldsymbol{N}$, The density of AC3 is increased in Nestin-Cre; $T b r 2^{\text {flox/flox }}$ mice, indicating that cell death is increased during this period of premature neurogenesis in mutants ( $\boldsymbol{N}$, arrows). $\mathbf{O}, \mathbf{P}, \mathrm{By} P 3$, the suprapyramidal blade of the DG is easily identifiable in control mice and contains numerous NeuroD1 ${ }^{+}$neuroblasts, whereas these cells are reduced and misplaced in Nestin-Cre;Tbr2 ${ }^{\text {flox/flox }}$ mice. Scale bars: $\boldsymbol{A}, 100 \mu \mathrm{m} ; \boldsymbol{A} \mathbf{1}, 50 \mu \mathrm{m} ; \boldsymbol{C}, 100 \mu \mathrm{m} ; \mathbf{G}, 100 \mu \mathrm{m} ; \mathbf{G 1}, 35 \mu \mathrm{m} ; \mathbf{I}, 35 \mu \mathrm{m} ; \boldsymbol{I}$ (inset), $20 \mu \mathrm{m} ; \boldsymbol{K}, 100 \mu \mathrm{m} ; \boldsymbol{K} \mathbf{1}, 35 \mu \mathrm{m} ; \boldsymbol{M}, 75 \mu \mathrm{m} ; \mathbf{0}, 75 \mu \mathrm{m}$. Regions delineated by dashed white boxes are shown in higher magnification in their respective adjacent panels. 

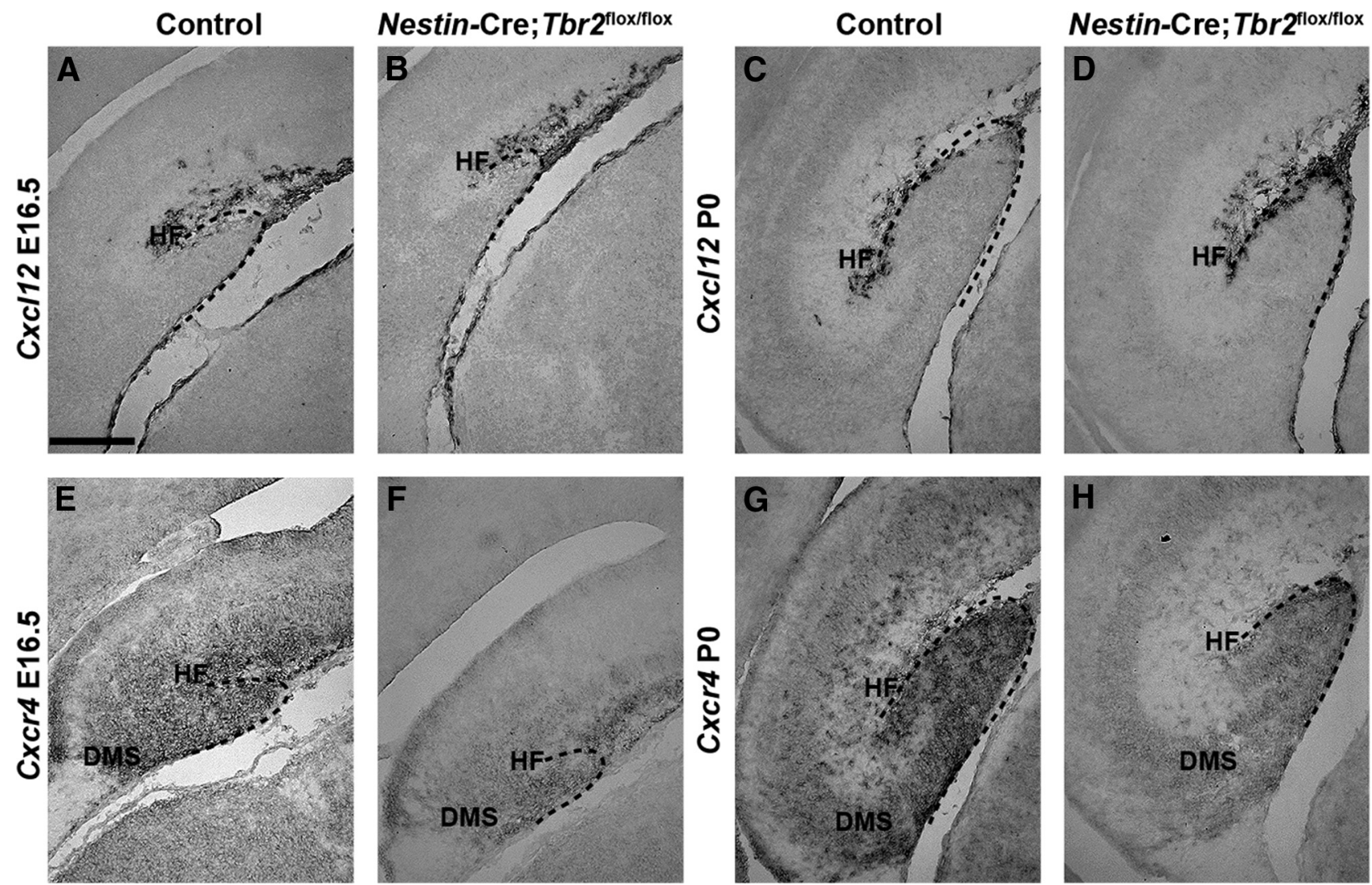

Figure 6. CXcr4 is downregulated in the DG of Nestin-Cre;Tbr2 ${ }^{\text {flox/flox }}$ mice. A-D, CXcl12 expression is apparent in the meninges in the HF in both control and Nestin-Cre; Tbr $2^{\text {flox/flox }}$ mice at E16.5 and P0. Expression of $\mathrm{C} x \mathrm{Cl} 12$ on a per cell basis appears normal in Nestin-Cre; $\mathrm{Tbr} 2^{\text {flox/flox }}$ mice at both ages, although reduction of the HF and decreased numbers of $\mathrm{CxCl12-expressing} \mathrm{cells} \mathrm{in} \mathrm{the} \mathrm{HF}$ are readily apparent in mutants. $\mathbf{E}-\boldsymbol{H}, \mathrm{CXCr} 4$, the receptor for $\mathrm{CXCl12}$ that is expressed on migrating progenitors and neuroblasts, is downregulated in the DG of Nestin-Cre; Tbr ${ }^{\text {flox/flox }}$ mice compared with controls at both E16.5 and PO. Scale bar: $A, 100 \mu \mathrm{m}$.

5I), as did Prox $1^{+} / \mathrm{PCNA}^{+}$cells (Fig. $5 \mathrm{H} 2$ ). Quantification of the proportion of total Sox $2^{+}$cells coexpressing Prox1 revealed a significant increase in coexpression of these TFs in Nestin-Cre;Tbr2 $2^{\text {flox/llox }}$ mice $(48.8 \pm 1.0 \%, p<0.01 ; t$ test; $N=3)$ compared with controls $(11.3 \pm 7.2 \%)$. In contrast, in control animals, Prox1 was typically expressed in granule neuroblasts that were predominantly Nestin-GFP ${ }^{-} / \mathrm{Sox}^{-}$, and Prox1 and Sox 2 were very rarely expressed in the same cells in control embryos (Fig. 5I-I3).

Given that newborn Prox ${ }^{+}$neuroblasts aberrantly coexpressed NSC markers in Nestin-Cre; Tbr $2^{\text {flox/flox }}$ mice, we postulated that this might lead to increased cell death in mutants. Accordingly, there was a marked increase in cell death in the DMS and DG of mutants on E17.5 as revealed by immunostaining for AC3 (Fig. $5 \mathrm{M}, N$ ). Quantification of $\mathrm{AC}^{+}$cells revealed a significant increase in Nestin-Cre; Tbr $2^{\text {flox/flox }}$ mice $(83.8 \pm 2.1$ cells/ $\left.\mathrm{mm}^{2}\right)$ compared with controls $\left(34.02 \pm 3.2\right.$ cells $/ \mathrm{mm}^{2} ; t$ test; $p<$ $0.001 ; N=3$ ), confirming that many of these early generated neuroblasts indeed did not survive. Accordingly, by P3, the number of NeuroD1 ${ }^{+}$neuroblasts was reduced in Nestin-Cre; $\mathrm{Tbr} 2^{\text {flox/flox }}$ mice with scattered and misplaced NeuroD1 $1^{+}$cells present in a reduced suprapyramidal DG blade and hilus (Fig. $5 O, P)$. Importantly, increased generation of Prox $1^{+}$neuroblasts appeared to be transient in Nestin-Cre; Tbr $2^{\text {flox/flox }}$ mice and was restricted to E15.5 to E17.5. After this time, a reduction in NeuroD $1^{+}$and Prox $1^{+}$neuroblasts was observed in mutants, similar to our previous report (Hodge et al., 2012). Additionally, we did not observe any increase in $\mathrm{NeuroD}^{+}$neuroblasts in Nestin-CreER ${ }^{\mathrm{T} 2} ; \mathrm{Tbr} 2^{\text {flox/flox }}$ mice in which tamoxifen was given to knock-out Tbr2 between E13.5 and E14.5 (Fig. 4I,J). Therefore, the transient increase in neuroblasts seen in Nestin-Cre; $\mathrm{Tbr} 2^{\text {flox/flox }}$ animals appeared to result from the specific environmental circumstances in which the DG developed in these particular mutants.

Interestingly, the premature neurogenesis observed in Nestin-Cre; Tbr2 $2^{\text {flox/flox }}$ mice between E15.5 and E17.5 resembled that previously reported in Cxcr4 knock-out animals (Li et al., 2009). To determine whether alterations in this chemokine signaling pathway may account in part for the burst of premature neuroblast generation seen in Nestin-Cre; $\mathrm{Tbr} 2^{\text {flox/flox }}$ animals, we examined expression of the Cxcr 4 receptor and one of its ligands, Cxcl12, in control and mutant animals at several different stages of DG development (Fig. 6). We found that, although Cxcl12 seemed to be expressed at approximately normal levels on a per cell basis, it appeared that overall expression in the HF was slightly reduced in Nestin-Cre; Tbr $2^{\text {flox/flox }}$ mice at both E16.5 and P0 (Fig. $6 A-D$ ), likely because of the decreased number of CajalRetzius cells populating the HF and reduced invagination of the pia in mutant animals, as discussed previously. In contrast, expression of Cxcr4 was markedly decreased in the DMS and DG of Nestin-Cre; Tbr $2^{\text {flox/flox }}$ mice, consistent with the known expression of this receptor in migrating progenitors and neuroblasts (Berger et al., 2007), at both E16.5 and P0 (Fig. 6E-H). These findings suggest that perturbed chemokine signaling may contribute to aberrant migration and premature neurogenesis in Nestin-Cre; $T b r 2^{\text {flox/flox }}$ mice, similar to what has been reported in Cxcr4 knock-out animals (Li et al., 2009). 

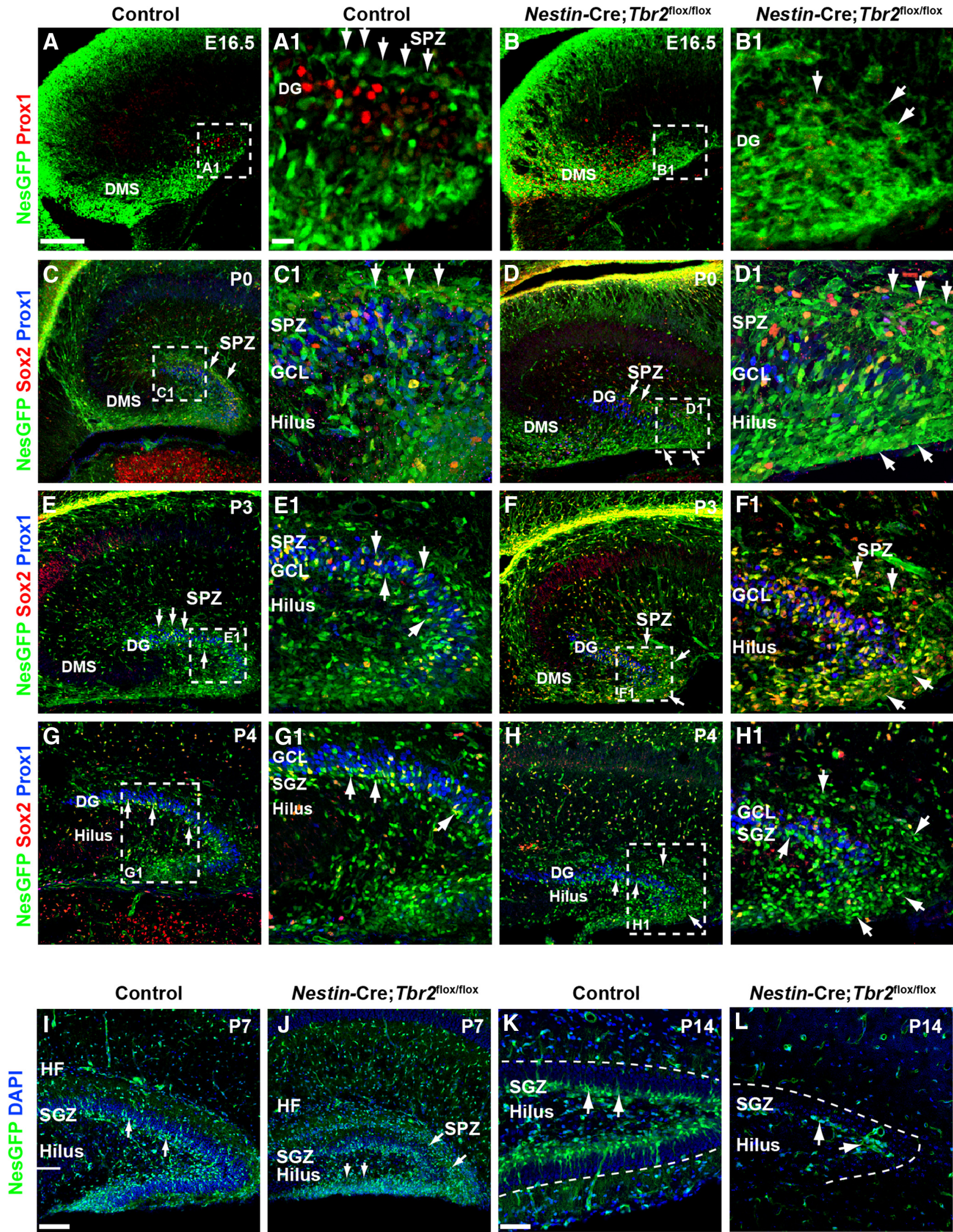

Nestin-Cre;Tbr2flox/flox

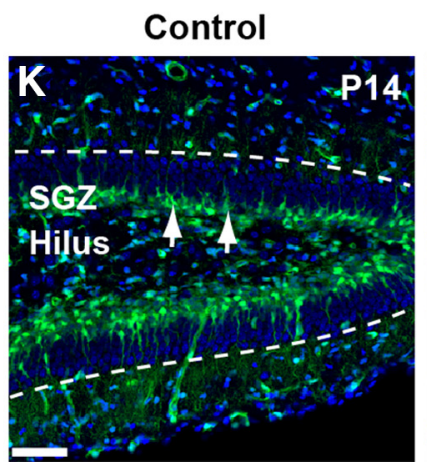

Nestin-Cre;Tbr2flox/flox
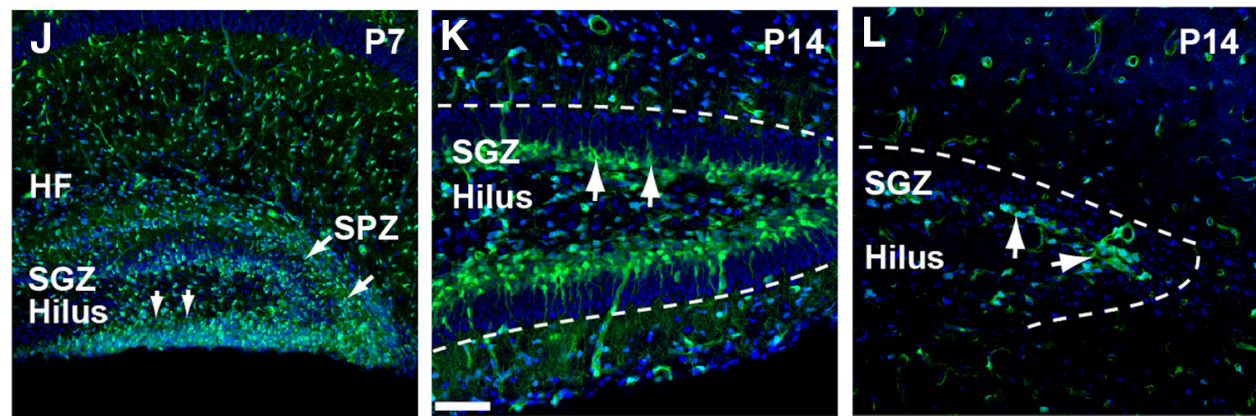

Figure 7. Development of the SGZ neurogenic niche is disrupted in Nestin-Cre;Tbr ${ }^{\text {floxfflox }}$ mice. $\boldsymbol{A}, \boldsymbol{A 1}$, The SPZ is apparent in controls by E16.5 as a layer of Nestin-GFP ${ }^{+}$(NesGFP) cells immediately above the Prox $1^{+}$neuroblasts populating the forming upper DG blade (A1, arrows). $\boldsymbol{B}, \boldsymbol{B} \mathbf{B}$, In Nestin-Cre; $T b r 2^{\text {flox/flox }}$ mice, there is a delay in the formation of the SPZ (B1, arrows). In controls, NesGFP ${ }^{+}$NSCs localize to the SPZ above the forming suprapyramidal blade on PO (C, C1, arrows). In Nestin-Cre;Tbr2 ${ }^{\text {flox/flox }}$ mice, increased (Figure legend continues.) 
Development of the SPZ and transition to the SGZ are disrupted in Nestin-Cre; $T b r 2^{\text {flox/flox }}$ mice

The SPZ is a transient neurogenic niche that forms around the pole of the developing DG during late stages of embryonic development (Li et al., 2009). Previous studies showed that the SPZ is present until approximately $\mathrm{P} 3-\mathrm{P} 4$, at which time some of the progenitor cells remaining in this zone transition through the GCL and contribute to the formation of the SGZ (Li et al., 2009). To determine whether conditional Tbr2 ablation impacted the development of the SPZ niche, we examined the migration of Nestin-GFP ${ }^{+} / \mathrm{Sox}^{+}$NSCs and INPs to the SPZ in Nestin-Cre; $T b r 2^{\text {flox/flox }}$ and control mice at several stages of development (Fig. 7). In control mice, the SPZ was apparent by E16.5 as Nestin-GFP ${ }^{+}$NSCs began to concentrate above the forming suprapyramidal DG blade adjacent to the molecular layer (Fig. $7 A, A 1)$. In contrast, Nestin-GFP ${ }^{+}$precursors failed to reach SPZ on E16.5 in Nestin-Cre; Tbr $2^{\text {flox/flox }}$ mice and were instead concentrated in the expanded DMS, consistent with aberrant expression of NSC markers in prematurely generated neuroblasts in mutant mice (Fig. 7 B, B1). By P0, the SPZ was well formed in control mice, as Nestin-GFP ${ }^{+}$NSCs were concentrated above Prox $1^{+}$neuroblasts in the forming upper blade of the DG (Fig. $7 C, C 1$, arrows). Many Nestin-GFP ${ }^{+}$cells in the SPZ were Sox $2^{+}$in P0 control mice (Fig. 7C1). Despite the delay we observed in SPZ formation in Nestin-Cre; Tbr2 $2^{\text {flox/lox }}$ mice at E16.5, this niche was apparent by $\mathrm{P} 0$ in mutants; interestingly, increased numbers of Nestin-GFP ${ }^{+} / \mathrm{Sox}{ }^{+}$NSCs were observed in the SPZ in these mice (Fig. $7 D, D 1$ ).

By P3, translocation of Nestin-GFP ${ }^{+}$NSCs through the upper GCL out of the SPZ had begun in control mice (Fig. $7 E, E 1$ ). At this time, Nestin-GFP ${ }^{+}$cells became increasingly concentrated in the hilus and forming SGZ in controls, as the generation of the lower (infrapyramidal) DG blade began (Fig. $7 E, E 1$ ). Conversely, Nestin-GFP ${ }^{+}$cells remained concentrated in the SPZ of Nestin-Cre; Tbr $2^{\text {flox/flox }}$ mice at P3 (Fig. 7 F, F1, arrows). By P4, the SPZ was largely depleted in control mice, and the majority of Nestin-GFP ${ }^{+}$NSCs were concentrated in the SGZ of the suprapyramidal blade and in the forming end of the lower blade (Fig. 7G,G1). In contrast, a large number of Nestin-GFP ${ }^{+}$NSCs remained in the SPZ of Nestin-Cre; Tbr $2^{\text {flox/flox }}$ mice at P4 (Fig. $7 \mathrm{H}, \mathrm{H1}$, arrows) and were somewhat removed from the reduced suprapyramidal DG blade resulting from expansion of the SPZ. Scattered Nestin-GFP ${ }^{+}$progenitors were also observed in the SGZ in Nestin-Cre; Tbr2 ${ }^{\text {flox/flox }}$ mice and in the hilus and adjacent tip of the forming infrapyramidal blade (Fig. $7 H$ ). However, very few $\operatorname{Prox}^{+}$cells were seen in the lower blade in Nestin-Cre;Tbr $2^{\text {flox/flox }}$ mice at P4 (Fig. $7 \mathrm{H1}$ ), in contrast with

\footnotetext{
(Figure legend continued.) numbers of NesGFP ${ }^{+} / \mathrm{Sox2}{ }^{+}$cells are apparent in the SPZ on PO (D, D1, arrows). By P3, NesGFP ${ }^{+}$progenitors begin to transition out of the SPZ in control mice $(\boldsymbol{E}$, E1, arrows). In contrast, many NesGFP ${ }^{+} \mathrm{NSC}$ remain concentrated in the SPZ in Nestin-Cre; $T b r 2^{\text {flox/flox }}$ mice, although some do migrate through the GCL $(\boldsymbol{F}, \boldsymbol{F} 1)$. By P4, transition of NSCS out of the SPZ is largely complete in control mice, and the SGZ is apparent adjacent to the hilus ( $\mathbf{G}, \mathbf{G 1}$, arrows). In mutant mice on $\mathrm{P4}$, NesGFP ${ }^{+} \mathrm{NSC}$ s remain concentrated in the SPZ and are reduced in the SGZ $\left(\boldsymbol{H}, \boldsymbol{H 1}\right.$, arrows). In controls, NesGFP ${ }^{+} \mathrm{NSC}$ are apparent in the SGZ, and the transitory SPZ is essentially gone by P7 (I). At P7, many NesGFP ${ }^{+}$NSCs remain in the SPZ in Nestin-Cre;Tbr2 $2^{\text {flox/flox }}$ mice (J, arrows) and are also present in the hilus. By P14, NesGFP ${ }^{+}$progenitor cells are exclusively found in the SGZ in control mice $(\boldsymbol{K})$. In Nestin-Cre; $T b r 2^{\text {flox/flox }}$ mice, the SGZ is present, but is reduced in size $(\boldsymbol{L})$ with very few Nes$\mathrm{GFP}^{+}$NSCS present. Scale bars: $\boldsymbol{A}, 100 \mu \mathrm{m} ; \boldsymbol{A} \mathbf{1}, 25 \mu \mathrm{m} ; \boldsymbol{I}, 75 \mu \mathrm{m} ; \boldsymbol{K}, 30 \mu \mathrm{m}$. Regions delineated by dashed white boxes are shown in higher magnification in their respective adjacent panels.
}

controls where new neuroblasts were beginning to expand the lower blade (Fig. 7G1). By P7, translocation of Nestin-GFP ${ }^{+}$progenitors out of the SPZ was essentially complete in control mice, and the SGZ was readily identifiable, particularly in the upper GCL (Fig. 7I, arrows), although scattered Nestin-GFP ${ }^{+}$progenitors could still be seen migrating through the GCL. In P7 Nestin-Cre; $T b r 2^{\text {flox/flox }}$ mice, Nestin-GFP ${ }^{+}$NSCs persisted in the SPZ, as they did in earlier stages of development, and few of these NSCs were present in the SGZ of the suprapyramidal GCL (Fig. $7 J)$. Strikingly, granule neurons were largely absent from the infrapyramidal blade in Nestin-Cre; $\mathrm{Tbr} 2^{\text {flox/flox }}$ mice at P7; instead, this region was populated by Nestin-GFP ${ }^{+}$NSCs (Fig. 7J). The suprapyramidal blade of the DG was also obviously reduced in size by P7 in mutant mice (Fig. 7J). In control mice, the SGZ was clearly formed by P14, and the majority of remaining Nestin$\mathrm{GFP}^{+}$NSCs had localized to this zone by this time (Fig. $7 \mathrm{~K}$ ). In contrast, the SGZ of Nestin-Cre; Tbr $2^{\text {flox/flox }}$ mice was greatly reduced, consisting only of scattered Nestin-GFP ${ }^{+}$NSCs (Fig. 7L). These results suggest that a lasting DG neurogenic niche was essentially absent from mutant mice (Fig. $7 L$ ), consistent with previous reports of $\mathrm{Tbr} 2$ conditional mutant mice (Arnold et al., 2008).

\section{Consequences of loss of Tbr2 for DG development and function}

By the end of DG development (P25; Fig. 8A,B), the DG was greatly reduced in Nestin-Cre; $\mathrm{Tbr} 2^{\text {flox/flox }}$ mice. The infrapyramidal blade largely failed to form in mutant mice, and the suprapyramidal blade was truncated and significantly thinner in Nestin-Cre;Tbr $2^{\text {flox/llox }}$ mice (Fig. 8 A,B). Accordingly, the mossy fiber pathway (the main output of the DG to the hippocampal CA3 field) was markedly reduced in Nestin-Cre; $\mathrm{Tbr} 2^{\text {flox/flox }}$ mice, as illustrated by reduced calbindin immunostaining of these axonal projections at $\mathrm{P} 14$ (Fig. 8C,D). However, despite ablation of Tbr2 early in DG development, some Prox $1^{+} /$Calbindin $^{+}$granule neurons were generated in Nestin-Cre; $\mathrm{Tbr} 2^{\text {flox/flox }}$ mice (Fig. $8 E, F)$. These results suggest that either some NSCs escape Nestin-Cre-mediated deletion of Tbr2 and go on to produce granule neurons in Nestin-Cre; $T b r 2^{\text {flox/flox }}$ mice, or that a small population of NSCs/INPs do not require Tbr2 to produce granule neurons and generate the cells populating the suprapyramidal blade in Nestin-Cre; $\mathrm{Tbr} 2^{\text {flox/flox }}$ mice.

Given the apparent reduction in mossy fibers and truncation of the DG, we next wanted to test for electrophysiological abnormalities in granule neurons of Nestin-Cre; Tbr $2^{\text {flox/flox }}$ mice (Fig. $8 G$ ). To do so, whole-cell patch-clamp recordings were made in representative DG granule neurons of both Nestin-Cre; $T b r 2^{\text {flox/flox }}(n=9)$ and control $(n=6)$ hippocampal slices (Fig. $8 G)$. These recordings indicated no significant differences in steady-state $\mathrm{V}_{\mathrm{m}}$ (membrane potential) between groups (81 \pm 2 $\mathrm{mV}$ Nestin-Cre; $T b r 2^{\text {flox/flox }}$ vs $79 \pm 3 \mathrm{mV}$ control). Interestingly, in $33 \%$ of granule neurons recorded in Nestin-Cre; $T b r 2^{\text {flox/llox }}$ mice, injection of $20 \mathrm{pA}$ of current-evoked action potentials compared with only $14 \%$ of control granule neurons. However, $\mathrm{R}_{\mathrm{n}}$ in Nestin-Cre; $\mathrm{Tbr} 2^{\text {flox/flox }}$ granule neurons was significantly smaller $(218 \pm 16 \mathrm{M} \Omega)$ than $\mathrm{R}_{\mathrm{n}}$ in control granule neurons $(280 \pm 24 \mathrm{M} \Omega$; $t$ test; $p<0.05)$ (Fig. $8 G)$. Therefore, although no differences between Nestin-Cre; Tbr2 $2^{\text {flox/flox }}$ and control neurons were observed with respect to steady-state $V_{m}$, a larger percentage of mutant neurons exhibited evoked action potentials. Furthermore, as $\mathrm{R}_{\mathrm{n}}$ is a reflection of cell geometry and size as well as the density of ion channels open at resting, the significantly smaller $\mathrm{R}_{\mathrm{n}}$ of Nestin-Cre; Tbr2 $2^{\text {flox/llox }}$ granule neurons suggests that these 


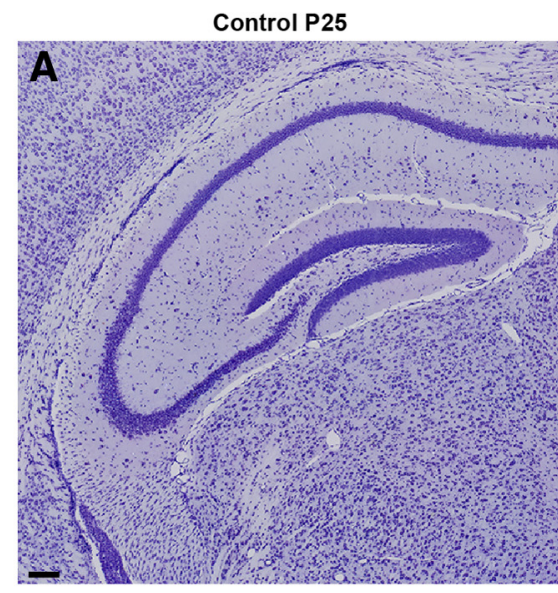

Control P14
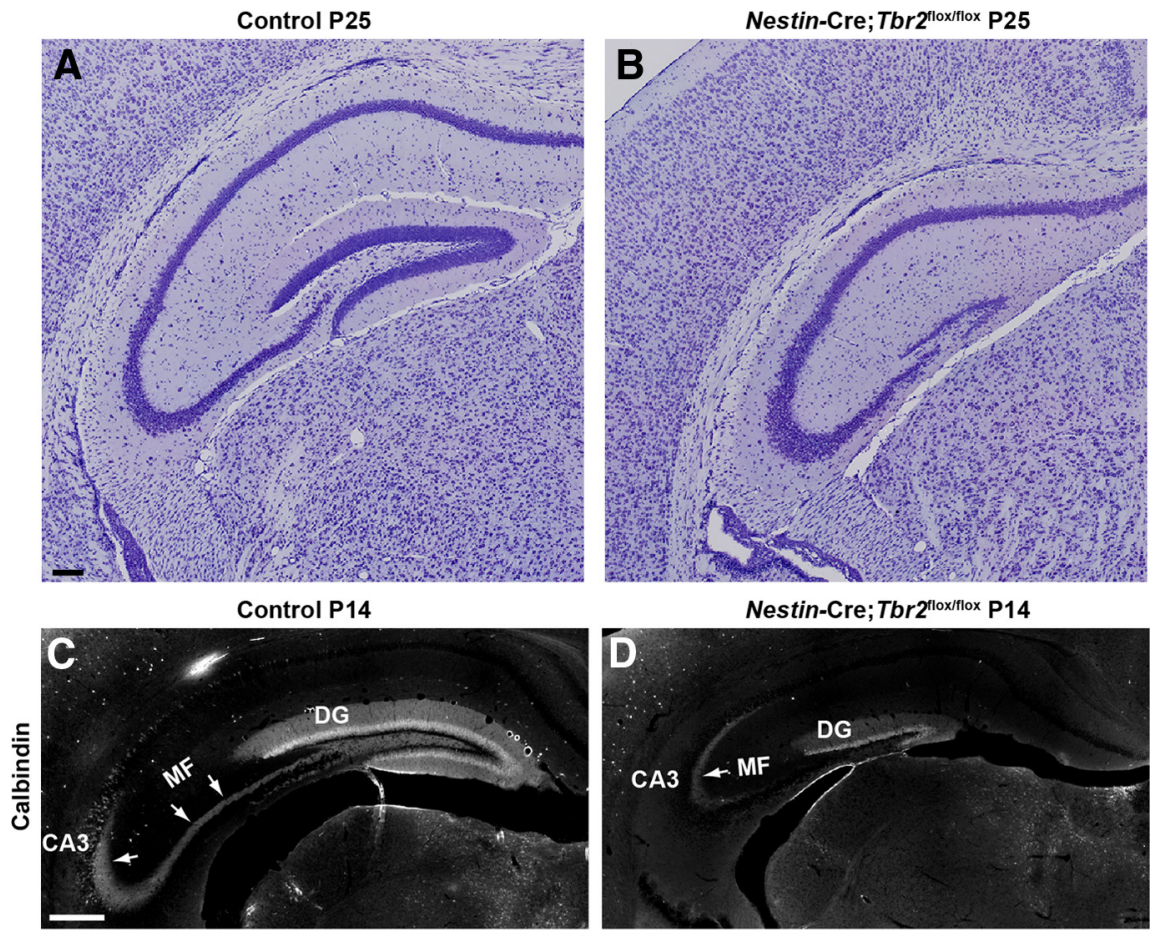

Nestin-Cre;Tbr2 $2^{\text {flox/flox }} \mathbf{P} 14$
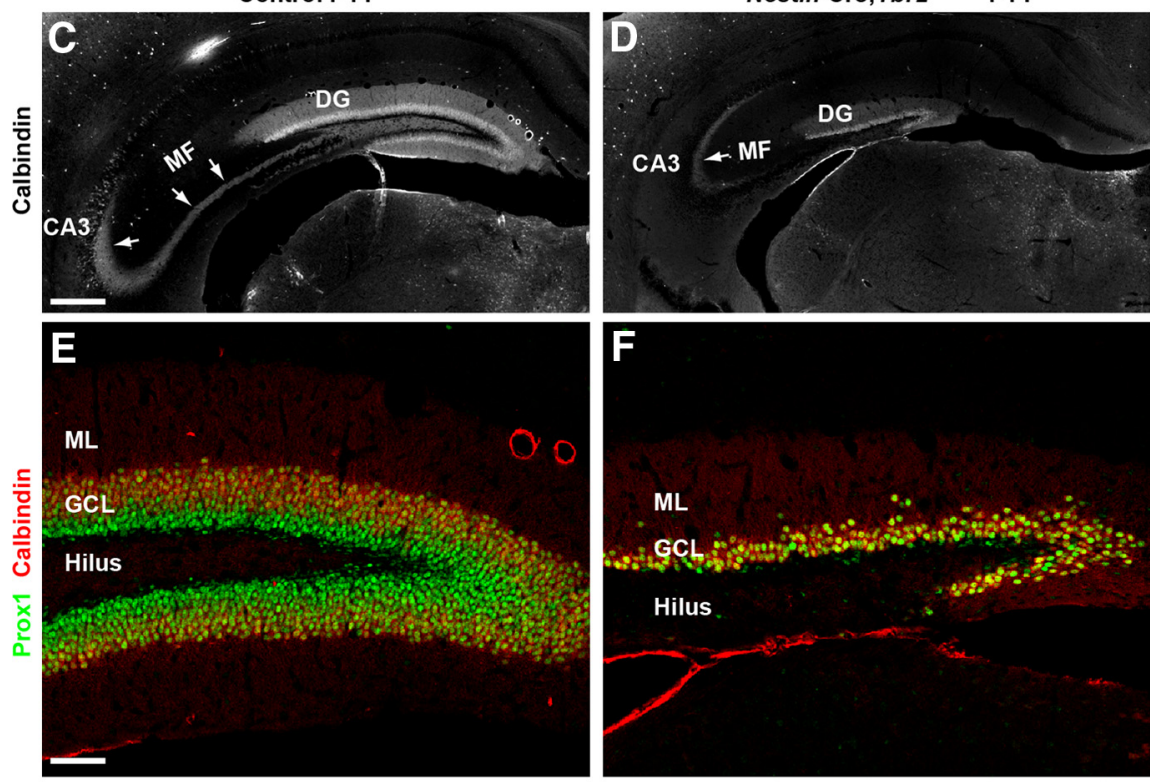

G Control

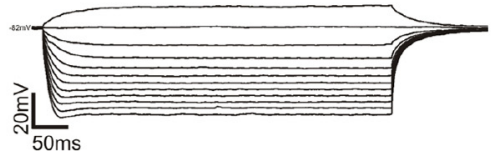

Nestin-Cre;Tbr2 ${ }^{\text {flox/flox }}$

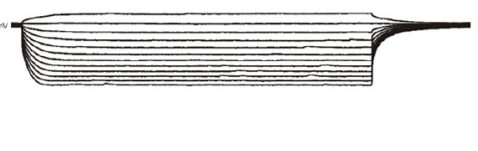

Figure 8. Tbr2 ablation has severe consequences for DG morphogenesis. $A, B$, By early postnatal development, the DG of control mice is fully formed, whereas the DG of Nestin-Cre; $T b r 2^{\text {flox/flox }}$ mice consists only of a truncated and thinned suprapyramidal blade. $\boldsymbol{B}$, The infrapyramidal blade of the GCL essentially fails to form in Nestin-Cre;Tbr2 ${ }^{\text {flox/flox }}$ mice. $\boldsymbol{C}$, The mossy fiber pathway (MF), the main output of the DG granule neurons to $C A 3$, is easily distinguished by immunostaining for calbindin at P14 in control animals ( $\boldsymbol{C}$, arrows). $\boldsymbol{D}$, In mutant mice, the MF pathway is greatly reduced ( $\boldsymbol{D}$, arrow) because of the decrease in DG size. $\boldsymbol{E}, \boldsymbol{F}$, The cells that remain in the DG of Nestin-Cre;Tbr2 ${ }^{\text {flox/flox }}$ mice appear to be granule neurons as evidenced by their expression of Prox 1 and calbindin. However, the number of granule neurons populating the DG is clearly greatly reduced in mutant mice $(\boldsymbol{F})$ compared with controls $(\boldsymbol{E})$. G, Representative I-V curves from control and Nestin-Cre;Tbr $2^{\text {flox/flox }}$ mice illustrate that input resistance is significantly decreased in granule neurons remaining in the reduced DG of mutant mice compared with controls. Scale bars: $\boldsymbol{A}, 100 \mu \mathrm{m}$; C, $100 \mu \mathrm{m} ; \boldsymbol{E}, 100 \mu \mathrm{m}$.

cells are potentially different both functionally and anatomically from control neurons. Previous reports indicate that $R_{n}$ varies with the stage of maturity and anatomical position of given DG neurons (Toni et al., 2008; Mongiat et al., 2009). Hence, the observed differences in $R_{n}$ suggest that the spared DG neurons in Nestin-Cre; $\mathrm{Tbr} 2^{\text {flox/flox }}$ mice are not fully integrated into the local circuitry, express a different compliment/proportion of intrinsically active channel conductances, and/or are smaller.

\section{Discussion}

In the present study, we identify novel functions of Tbr2 in Cajal-Retzius cells and INPs during morphogenesis of the DG, affirming the importance of this transcription factor in regulating many aspects of DG development (Fig. 9). Although a previous study showed that conditional ablation of Tbr2 during embryonic development (Sox1-Cre) impacted DG formation, producing a similar phenotype to the one we have described (Arnold et al., 2008), abnormalities in DG development in this previous study were largely attributed to increased postnatal cell death. We also find increased cell death in our Nestin-Cre;Tbr2 $2^{\text {flox/flox }}$ model, but we propose that this is a downstream outcome of loss of Tbr2 function that does not fully account for the complex phenotype we observe. Rather, we show that ablation of $T b r 2$ in several different cell types impacts multiple steps in DG development that cumulatively result in abnormal morphogenesis, decreased granule neuron production, and altered granule neuron function (Fig. 9).

Previous work from our laboratory and others showed that $T b r 2$ is expressed specifically in INPs from the start of DG development through to adulthood and established a critical role for Tbr2 in regulating granule cell neurogenesis (Hodge et al., 2008; Roybon et al., 2009; Hodge et al., 2012). Here we show that Tbr2 is expressed not only in DG INPs but also in the lineage of progenitor cells giving rise to cortical hem-derived Cajal-Retzius cells, and we demonstrate that Tbr2 has functions within these cells distinct from its role in INPs. Specifically, we show that $T b r 2$ is required for proper migration of Cajal-Retzius cells from their place of birth in the cortical hem to the HF during early establishment of the DG (Fig. 9). Our results indicate that aberrant migration of Cajal-Retzius cells to the developing DG may have several downstream consequences for morphogenesis of the GCL that might account for much of the phenotype we observe in Nestin-Cre; $T b r 2^{\text {flox/llox }}$ mice. The first of these defects is impaired development of the transhilar radial glial scaffold (Fig. 9). The importance of Cajal-Retzius cells in establishing this scaffold was first described in reeler mice, which are deficient in Reelin expression and lack radially oriented $\mathrm{Gfap}^{+}$processes consistent with aberrations in the radial glial scaffold (Frotscher et al., 2003; Weiss et al., 2003). Indeed, the DG of Nestin-Cre; $T b r 2^{\text {flox/flox }}$ mice bears some resemblance to that of reeler mice, including decreased pial invagination of the HF during early DG morphogenesis (Forster et al., 2002; Weiss et al., 
A

$$
\text { E15.5-E16.5 }
$$

Control

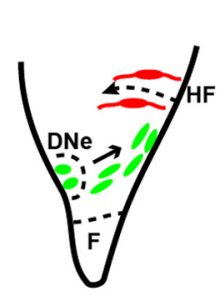

Nestin-Cre;Tbr2 flox/flox

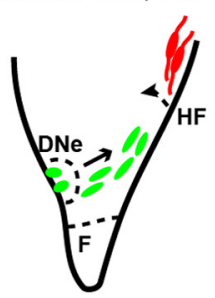

E19.5-P0

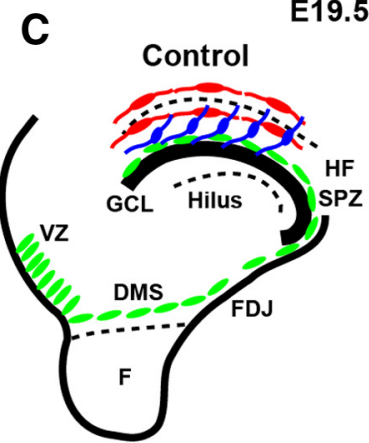

Nestin-Cre;Tbr2 flox/flox

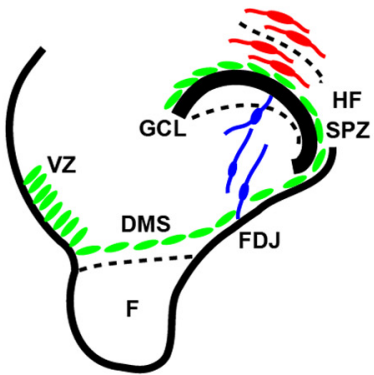

P5-P7
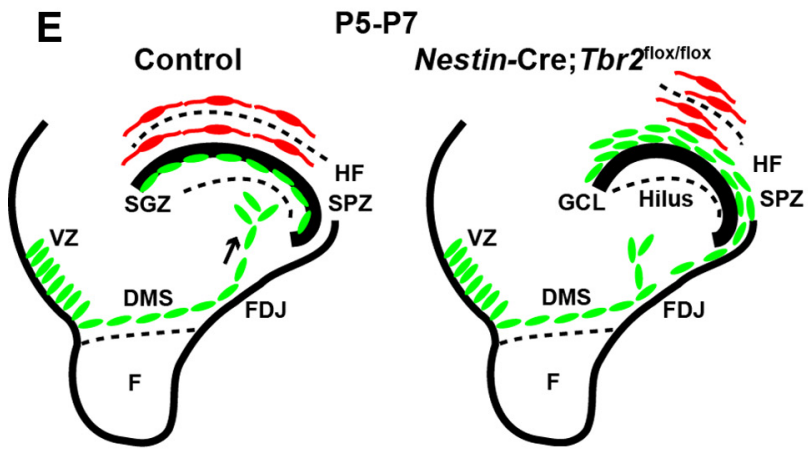

$\mathbf{F}$

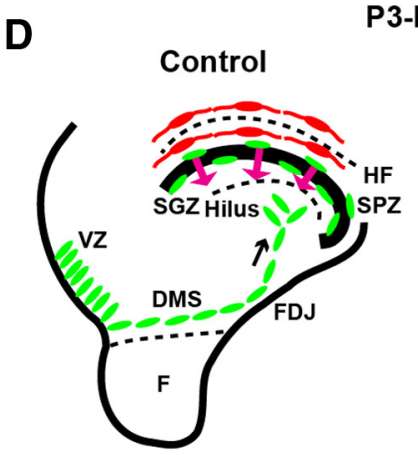

E18.5-E19.5
B

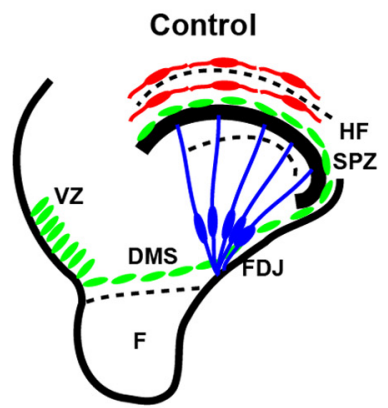

Nestin-Cre; Tbr2 $2^{\text {flox/flox }}$

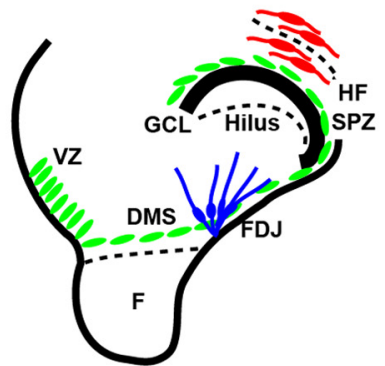

P3-P4
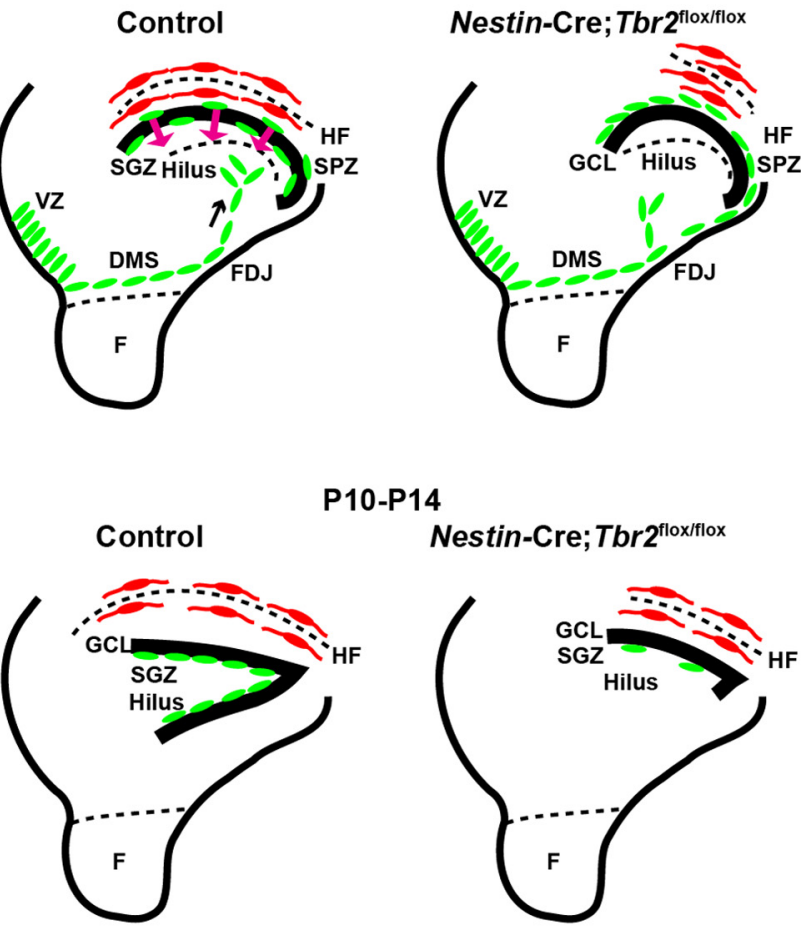

P10-P14

- Progenitor cells (NSCs and INPs)

\section{Cajal-Retzius cells}

Radial glial cells of the transhilar glial scaffold

Figure 9. Schematic diagram summarizing DG defects in Nestin-Cre;Tbr ${ }^{\text {flox/flox }}$ mice. $\boldsymbol{A}$, Initial invagination of the pial surface is delayed in Nestin-Cre; $T b r 2^{\text {flox/flox }}$ mice, and the migration of Cajal-Retzius cells (red) to the forming HF is delayed in mutants. B, Development of the transhilar radial glial scaffold (blue cells) is abnormal in Nestin-Cre; Tbr2 ${ }^{\text {flox/flox }}$ mice by E18.5-E19.5, and the number of Cajal-Retzius cells (red) populating the HF is reduced. $C$, Blbp ${ }^{+}$radial glial cells (blue) that contribute to the transhilar radial glial scaffold complete their redistribution to the HF by E19.5-P0 in control mice, but this migration is delayed in Nestin-Cre; Tbr2 ${ }^{\text {flox/flox }}$ mice. D, During early postnatal development (P3-P4), progenitor cells (green) populating the transient SPZ are redistributed to form the SGZ niche. In Nestin-Cre; Tbr2 ${ }^{\text {flox/flox }}$ mice, these cells are retained in the SPZ and fail to migrate to the SGZ.E, Formation of the SGZ (green, progenitor cells) is complete by P5-P7 in control mice, and the SPZ is no longer apparent. In mutant mice, retention of progenitors in the SPZ persists. $F$, By P10-P14, both the suprapyramidal and infrapyramidal blades of the DG are formed in control mice, and progenitor cells (NSCs and INPs, green) are localized to the SGZ. In Nestin-Cre;Tbr2 ${ }^{\text {flox/flox }}$ mice, the infrapyramidal blade fails to form, the suprapyramidal blade is reduced in size, and progenitor cells are nearly absent from the SGZ (green).

2003). Likewise, scrambler mice, which are deficient in Dab1, an intracellular adaptor protein that acts downstream of Reelin, exhibit similar defects in the transhilar radial glial scaffold, further emphasizing the importance of Reelin in orchestrating early DG morphogenesis (Weiss et al., 2003). We show that when Tbr2 is ablated after the birth of Cajal-Retzius cells in tamoxifen-induced Nestin-CreER ${ }^{\mathrm{T} 2} ; \mathrm{Tbr} 2^{\text {flox/flox }}$ mice, Reelin ${ }^{+}$cells develop and migrate to the HF, and, in turn, the transhilar glial scaffold develops normally. Thus, abnormalities in DG morphogenesis are largely abrogated when Cajal-Retzius cells develop and migrate on schedule, and Tbr 2 is a critical regulator of Cajal-Retzius cell development. Granule cell neurogenesis, on the other hand, remains impaired in Nestin-CreER ${ }^{\mathrm{T} 2} ; \mathrm{Tbr}^{\text {flox/flox }}$ mice, consistent with the known role of Tbr2 in regulating granule neuron differentiation (Hodge et al., 2012). These results highlight the distinct roles of Tbr2 in CajalRetzius progenitors and granule neuron progenitors (INPs) and emphasize the fact that Tbr2 must be expressed in both of these populations in order for the DG to develop properly. 
Aberrations in the transhilar radial glial scaffold in Nestin-Cre; $\mathrm{Tbr} 2^{\text {flox/flox }}$ mice likely initiate a cascade of events that lead to further impairments of DG development, including delayed transit of progenitor cells to the forming SPZ. Given that the glial scaffold is thought to act as a guide for migrating cells (Forster et al., 2002; Frotscher et al., 2003; Li et al., 2009), it is possible that physical defects in this scaffold (i.e., lack of radial process orientation) delay migration of progenitors to the forming SPZ. It is likewise possible that changes in expression of Reelin itself, which has been implicated in regulating granule cell migration (Frotscher et al., 2003; Sibbe et al., 2009), contribute to delayed establishment of the SPZ in Nestin-Cre; Tbr $2^{\text {flox/flox }}$ mice, particularly because we have shown that fewer Reelin ${ }^{+}$cells populate the HF at E16.5. However, others have reported that Reelin is not explicitly required for migration of progenitors to the SPZ, but rather that the $C x c l 12 / C x c r 4$ chemokine signaling pathway is key for formation of the SPZ (Li et al., 2009). Interestingly, we show that this pathway is also disrupted in the DG of mutant mice and that Nestin-Cre;Tbr2 ${ }^{\text {flox/flox }}$ mice share many similarities with Cxcr4 knock-out mice. Indeed, in Cxcr4 knock-out mice, formation of the transhilar radial glial scaffold is abnormal, with reduced Gfap ${ }^{+}$processes present in the hilus (Bagri et al., 2002; Li et al., 2009). As well, Blbp ${ }^{+}$cells fail to localize to the hilus and HF in Cxcr4-null mice, and instead remain in the FDJ as we observed in Nestin-Cre; Tbr $2^{\text {flox/flox }}$ mice (Li et al., 2009). These findings suggest that downregulation of Cxcr4 after Tbr2 ablation likely impairs migration to the forming DG. Interestingly, during early DG development, Cxcl12 expression from the meninges is thought to regulate positioning of Cajal-Retzius cells in the dentate marginal zone (Paredes et al., 2006), suggesting that these two signaling pathways may work in concert to control early events in DG morphogenesis. Thus, the phenotype we describe in Nestin-Cre; Tbr $2^{\text {flox/flox }}$ mice may be the product of defective interplay between the Reelin and chemokine signaling pathways.

In addition to aberrant glial scaffold development, Cxcr4-null mutants also exhibit an early burst of neurogenesis in the DMS that accompanies delayed migration of progenitors to the SPZ ( $\mathrm{Li}$ et al., 2009), similar to Nestin-Cre; Tbr $2^{\text {flox/flox }}$ mice. Previous reports suggest that normal migration of NSCs/INPs to the DG and proper timing of differentiation are intrinsically coupled during early stages of DG development, with delayed progenitor migration resulting in early neuroblast generation in the DMS (Li et al., 2009). Coupling of migration and differentiation has also been shown in the postnatal rostral migratory stream, where delayed transit to the olfactory bulb alters the fate and physiological functions of newborn neuroblasts (Belvindrah et al., 2011). We suggest that delayed transit of progenitors to the SPZ contributes to the burst of premature neuroblast generation we observe in Nestin-Cre; Tbr $2^{\text {flox/flox }}$ mice. Interestingly, we noted premature neurogenesis only in embryonic Nestin-Cre;Tbr $2^{\text {flox/flox }}$ mice, suggesting that this phenomenon might be intrinsically coupled to the pace and timing of migration during early development when extensive migration of progenitors to the DG is underway. Indeed, we showed previously that granule neurons are reduced in postnatal Nestin-Cre; $T b r 2^{\text {flox/flox }}$ mice as a result of failed differentiation of NSCs and accumulation of Sox $2{ }^{+}$NSCs in the DG (Hodge et al., 2012). In addition, we previously established that Tbr2 likely represses Sox2 during the transition from NSCs to INPs in the DG (Hodge et al., 2012). This may provide an explanation for why we observed aberrant coexpression of Sox 2 and Prox 1 in Nestin-Cre;Tbr $2^{\text {flox/flox }}$ mice. Perhaps, in the absence of Tbr2, Sox 2 is not repressed during differentiation, resulting in the unusual coexpression of Sox 2 and Prox 1 that we noted in the
DMS of mutant mice. In any case, these perturbations clearly result in a cellular phenotype that is incompatible with cell survival; accordingly, we observed a substantial increase in cell death in the DG of Nestin-Cre;Tbr $2^{\text {flox/flox }}$ mice.

The existence of the SPZ and its role as a transient neurogenic niche that contributes to the generation of granule neurons and establishment of the SGZ has only been recognized recently (Li et al., 2009). We show here that several steps in the development of the SPZ are impacted by loss of Tbr2 expression. First, initial formation of the SPZ is affected in Nestin-Cre; Tbr $2^{\text {flox/flox }}$ mice, perhaps as a result of a Cxcr4/Cxcl12 and/or Reelin-dependent defect in migration of progenitors as discussed above. Additionally, our results indicate that NSCs fail to exit the SPZ in a timely fashion to contribute to the SGZ, and instead accumulate in the SPZ of mutant mice. Previous studies have shown that Reelin expression regulates exit of progenitor cells from the SPZ (Li et al., 2009). Thus, it is possible that the decreased number of CajalRetzius cells present in the Nestin-Cre; $\mathrm{Tbr} 2^{\text {flox/flox }} \mathrm{HF}$ results in a large enough reduction in available Reelin to influence the exit of progenitors from the SPZ. Further studies will be required to determine the exact mechanisms responsible for regulating the dynamics of SPZ progenitors and their transition from the SPZ to SGZ to fully understand the failure of these cells to exit the SPZ in Nestin-Cre; Tbr $2^{\text {flox/flox }}$ mice. In any case, our results indicate that Tbr2 is critically important for the development of this transient niche and for subsequent establishment of the SGZ, further highlighting the requirement for Tbr2 during DG morphogenesis.

\section{References}

Arnold SJ, Huang GJ, Cheung AF, Era T, Nishikawa S, Bikoff EK, Molnár Z, Robertson EJ, Groszer M (2008) The T-box transcription factor Eomes/ Tbr2 regulates neurogenesis in the cortical subventricular zone. Genes Dev 22:2479-2484. CrossRef Medline

Bagri A, Gurney T, He X, Zou YR, Littman DR, Tessier-Lavigne M, Pleasure SJ (2002) The chemokine SDF1 regulates migration of dentate granule cells. Development 129:4249-4260. Medline

Bedogni F, Hodge RD, Elsen GE, Nelson BR, Daza RA, Beyer RP, Bammler TK, Rubenstein JL, Hevner RF (2010) Tbrl regulates regional and laminar identity of postmitotic neurons in developing neocortex. Proc Natl Acad Sci U S A 107:13129-13134. CrossRef Medline

Belvindrah R, Nissant A, Lledo PM (2011) Abnormal neuronal migration changes the fate of developing neurons in the postnatal olfactory bulb. J Neurosci 31:7551-7562. CrossRef Medline

Berger O, Li G, Han SM, Paredes M, Pleasure SJ (2007) Expression of SDF-1 and CXCR4 during reorganization of the postnatal dentate gyrus. Dev Neurosci 29:48-58. CrossRef Medline

Englund C, Fink A, Lau C, Pham D, Daza RA, Bulfone A, Kowalczyk T, Hevner RF (2005) Pax6, Tbr2, and Tbr1 are expressed sequentially by radial glia, intermediate progenitor cells, and postmitotic neurons in developing neocortex. J Neurosci 25:247-251. CrossRef Medline

Förster E, Tielsch A, Saum B, Weiss KH, Johanssen C, Graus-Porta D, Müller U, Frotscher M (2002) Reelin, Disabled 1, and $\beta 1$ integrins are required for the formation of the radial glial scaffold in the hippocampus. Proc Natl Acad Sci U S A 99:13178-13183. CrossRef Medline

Frotscher M, Haas CA, Förster E (2003) Reelin controls granule cell migration in the dentate gyrus by acting on the radial glial scaffold. Cereb Cortex 13:634-640. CrossRef Medline

Grove EA, Tole S, Limon J, Yip L, Ragsdale CW (1998) The hem of the cerebral cortex is defined by the expression of multiple Wnt genes and is compromised in Gli3-deficient mice. Development 125:2315-2325. Medline

Gu X, Liu B, Wu X, Yan Y, Zhang Y, Wei Y, Pleasure SJ, Zhao C (2011) Inducible genetic lineage tracing of cortical hem derived Cajal-Retzius cells reveals novel properties. PLoS ONE 6:e28653. CrossRef Medline

Hevner RF, Hodge RD, Daza RA, Englund C (2006) Transcription factors in glutamatergic neurogenesis: conserved programs in neocortex, cerebellum, and adult hippocampus. Neurosci Res 55:223-233. CrossRef Medline 
Hodge RD, D'Ercole AJ, O'Kusky JR (2005) Increased expression of insulinlike growth factor-I (IGF-I) during embryonic development produces neocortical overgrowth with differentially greater effects on specific cytoarchitectonic areas and cortical layers. Brain Res Dev Brain Res 154:227237. CrossRef Medline

Hodge RD, Kowalczyk TD, Wolf SA, Encinas JM, Rippey C, Enikolopov G, Kempermann G, Hevner RF (2008) Intermediate progenitors in adult hippocampal neurogenesis: $\mathrm{Tbr} 2$ expression and coordinate regulation of neuronal output. J Neurosci 28:3707-3717. CrossRef Medline

Hodge RD, Nelson BR, Kahoud RJ, Yang R, Mussar KE, Reiner SL, Hevner RF (2012) Tbr2 is essential for hippocampal lineage progression from neural stem cells to intermediate progenitors and neurons. J Neurosci 32:62756287. CrossRef Medline

Imayoshi I, Ohtsuka T, Metzger D, Chambon P, Kageyama R (2006) Temporal regulation of Cre recombinase activity in neural stem cells. Genesis 44:233-238. CrossRef Medline

Intlekofer AM, Banerjee A, Takemoto N, Gordon SM, Dejong CS, Shin H, Hunter CA, Wherry EJ, Lindsten T, Reiner SL (2008) Anomalous type 17 response to viral infection by $\mathrm{CD} 8+\mathrm{T}$ cells lacking T-bet and eomesodermin. Science 321:408-411. CrossRef Medline

Lavado A, Oliver G (2007) Prox1 expression patterns in the developing and adult murine brain. Dev Dyn 236:518-524. CrossRef Medline

Li G, Pleasure SJ (2005) Morphogenesis of the dentate gyrus: what we are learning from mouse mutants. Dev Neurosci 27:93-99. CrossRef Medline

Li G, Kataoka H, Coughlin SR, Pleasure SJ (2009) Identification of a transient subpial neurogenic zone in the developing dentate gyrus and its regulation by Cxcl12 and Reelin signaling. Development 136:327-335. CrossRef Medline

Liu M, Pleasure SJ, Collins AE, Neobels JL, Naya FJ, Tsai MJ, Lowenstein DH (2000) Loss of BETA2/NeuroD leads to malformation of the dentate gyrus and epilepsy. Proc Natl Acad Sci U S A 97:865-870. Medline

Mignone JL, Kukekov V, Chiang AS, Steindler D, Enikolopov G (2004) Neural stem and progenitor cells in nestin-GFP transgenic mice. J Comp Neurol 469:311-324. CrossRef Medline

Mongiat LA, Espósito MS, Lombardi G, Schinder AF (2009) Reliable acti- vation of immature neurons in the adult hippocampus. PLoS ONE 4:e5320. CrossRef Medline

Paredes MF, Li G, Berger O, Baraban SC, Pleasure SJ (2006) Stromalderived factor-1 (CXCL12) regulates laminar position of Cajal-Retzius cells in normal and dysplastic brains. J Neurosci 26:9404-9412. CrossRef Medline

Pleasure SJ, Collins AE, Lowenstein DH (2000) Unique expression patterns of cell fate molecules delineate sequential stages of dentate gyrus development. J Neurosci 20:6095-6105. Medline

Roybon L, Hjalt T, Stott S, Guillemot F, Li JY, Brundin P (2009) Neurogenin 2 directs granule neuroblast production and amplification while NeuroD1 specifies neuronal fate during hippocampal neurogenesis. PLoS ONE 4:e4779. CrossRef Medline

Schwab MH, Bartholomae A, Heimrich B, Feldmeyer D, Druffel-Augustin S, Goebbels S, Naya FJ, Zhao S, Frotscher M, Tsai MJ, Nave KA (2000) Neuronal basic helix-loop-helix proteins (NEX and BETA2/NeuroD) regulate termina granule cell differentiation in the hippocampus. J Neurosci 20:3714-3724. Medline

Shimogori T, Banuchi V, Ng HY, Strauss JB, Grove EA (2004) Embryonic signalling centers expressing BMP, Wnt, and FGF proteins interact to pattern the cerebral cortex. Development 131:5639-5647. CrossRef Medline

Sibbe M, Förster E, Basak O, Taylor V, Frotscher M (2009) Reelin and Notch1 cooperate in the development of the dentate gyrus. J Neurosci 29:8578-8585. CrossRef Medline

Toni N, Laplagne DA, Zhao C, Lombardi G, Ribak CE, Gage FH, Schinder AF (2008) Neurons born in the adult dentate gyrus form functional synapses with target cells. Nat Neurosci 11:901-907. CrossRef Medline

Tronche F, Kellendonk C, Kretz O, Gass P, Anlag K, Orban PC, Bock R, Klein R, Schütz G (1999) Disruption of the glucocorticoid receptor gene in the nervous system results in reduced anxiety. Nat Genet 23:99-103. CrossRef Medline

Weiss KH, Johanssen C, Tielsch A, Herz J, Deller T, Frotscher M, Förster E (2003) Malformation of the radial glial scaffold in the dentate gyrus of reeler mice, scrambler mice, and ApoER2/VLDLR-deficient mice. J Comp Neurol 460:56-65. CrossRef Medline 